Maurice A. Deane School of Law at Hofstra University Scholarly Commons at Hofstra Law

Hofstra Law Faculty Scholarship

$11-2002$

\title{
Dual Resident Voting: Traditional Disenfranchisement and Prospects for Change
}

Ashira Ostrow

Hofstra University

Follow this and additional works at: https://scholarlycommons.law.hofstra.edu/faculty_scholarship

\section{Recommended Citation}

Ashira Ostrow, Dual Resident Voting: Traditional Disenfranchisement and Prospects for Change, 102 Colum. L. Rev. 1954 (2002) Available at: https://scholarlycommons.law.hofstra.edu/faculty_scholarship/746

This Article is brought to you for free and open access by Scholarly Commons at Hofstra Law. It has been accepted for inclusion in Hofstra Law Faculty Scholarship by an authorized administrator of Scholarly Commons at Hofstra Law. For more information, please contact lawcls@hofstra.edu. 


\title{
DUAL RESIDENT VOTING: TRADITIONAL DISENFRANCHISEMENT AND PROSPECTS FOR CHANGE
}

\author{
Ashira Pelman Ostrow
}

In modern times, a large and growing number of Americans qualify as bona fide residents of two or more locales. These dual residents are subject to local taxes and ordinances and are profoundly affected by policies that concern their second-home community. Yet, in most states, individuals are prohibited from voting in more than one location through voting statutes that equate residence with domicile. Recently, the Second Circuit upheld a New York election law that prevents second-home owners from voting in both of their residential districts. This Note argues that extending the franchise in local elections to individuals who qualify as bona fide residents of a community, regardless of whether they already qualify to vote in another community, is required under the Equal Protection Clause of the Fourteenth Amendment. Such an extension is also supported by normative arguments arising from the democratic tradition of government by the consent of the governed and against taxation without representation.

\section{INTRODUGTION}

No right is more precious in a free country than that of having a voice in the election of those who make the laws under which, as good citizens, we must live. Other rights, even the most basic, are illusory if the right to vote is undermined. Our Constitution leaves no room for classification of people in a way that unnecessarily abridges this right. ${ }^{\prime}$

While most Michigan property owners received a generous tax cut after a 1995 school financing ballot initiative boosted sales tax and reduced property tax, second-home owners, such as Frank Andress, found themselves subject to a substantial increase. ${ }^{2}$ The bill permitted school districts to impose a sizeable surtax on nonhomestead property, which includes second dwellings. A tax hike of this magnitude would normally send outraged voters to the polls; however Andress, and hundreds of others like him who spend a significant portion of the year in Michigan, but retain a primary residence elsewhere, are prohibited from voting in Michigan by a state law that limits voting to one's primary residential district. $^{3}$

1. Wesberry v. Sanders, 376 U.S. 1, 17-18 (1964).

2. John Flesher, Part-Time Residents Feel Taxed by Laws, Grand Rapids Press, Aug. 13,2000 , at A27.

3. Mich. Comp. Laws Ann. $\$ 168.11(1)$ (West 1989) (defining residence for registration and voting purposes as "that place at which a person habitually sleeps, keeps his or her personal effects and has a regular place of lodging" and noting that "[i]f a person has more than 1 residence ... that place at which the person resides the greater part of the time shall be his or her official residence for the purposes of this act"). 
Currently, in most states, as in Michigan, voting is restricted to one's residence. ${ }^{4}$ Residence, in the voting rights context, is generally equated with domicile, 5 and defined as "that place where a person maintains a fixed, permanent and principal home and to which he, wherever temporarily located, always intends to return." 6 The result in many states is that an individual can maintain only one residence for voting purposes. Thus, many individuals who otherwise qualify as bona fide residents of two districts can choose which residence to vote in, but are prohibited from voting in both. ${ }^{7}$

In modern times a number of factors, including improved methods of transportation, increased mobility, modern communications technology, and growing lifespans, have enabled many individuals to qualify as legitimate residents of two communities. ${ }^{8}$ In fact, according to 1995 census data, nearly ten percent of American households own more than one

4. See, e.g., Ala. Code $\$ 17-7-13$ (1995) (limiting voting to one residence); lnd. Code Ann. \$ 3-11-8-2 (Michie 1998) (restricting voting to place of residence); La. Rev. Stat. Ann. $\$ 18: 101$ (B) (West 1979) (requiring individuals with two residences to choose one for voting purposes); Minn. Stat. Ann. $\$ 201.016$ (West 1992) (limiting voting to a single place of residence); Mont. Code Ann. $\$ 13-1-113$ (2001) (permitting only one residence for voting purposes).

5. Hadnott v. Amos, 320 F. Supp. 107, 114 (M.D. Ala. 1970) ("For election law purposes 'resident' means a domiciliary."), aff'd per curiam, 401 U.S. 968 (1971); Restatement (Second) of Conflict of Laws $\$ 11 \mathrm{cmt}$. k (1989) (equating residence with domicile in election statutes); Joseph H. Beale, Residence and Domicil, 4 lowa L. Bull. 3, 5 (1918) ("[R]esidence as a qualification for voting means domicil."); Willis L. M. Reese \& Robert S. Green, That Elusive Word, "Residence," 6 Vand. L. Rev. 561, 571 (1953) ("So far as eligibility to vote is concerned [residence] is usually synonymous with domicil.").

6. N.Y. Elec. Law \$ 1-104(22) (McKinney 1998); see also Ind. Code Ann. § 3-5-2-42.5 (defining residence as that place where a person has a permanent home and principal establishment and to which the person has, whenever absent, the intention of returning); Kan. Stat. Ann. § 25-407 (2000) (same); Ky. Rev. Stat. Ann. \$ 116.035(1) (Michie 1993) (same). Some indicators of residence frequently included in state election law statutes are the individual's employment; income sources; residence for tax purposes; marital status; residence of parents, spouse, or children; sites of personal or real property; and motor vehicle or other personal property registration. See, e.g., Ga. Code Ann. \$21-2-217(b) (1998 \& Supp. 2001) (listing factors to be used in determining residence for voting); N.Y. Elec. Law. \$ 5-104(2) (same).

7. See, e.g., Ala. Code $\$ 17-7-13$ (limiting voting to one residence); La. Rev. Stat. Ann. $\$ 18: 101$ (B) ("If a citizen resides at more than one place in the state with an intention to reside there indefinitely, he may register and vote only at one of the places at which he resides."); Mont. Code Ann. \$13-1-113 (permitting only one residence for voting purposes); Ferguson v. McNab, 454 N.E.2d 532, 533 (N.Y. 1983) (finding that candidate with two legitimate residences can choose either as residence for election law); 1sabella $v$. Hotaling, 615 N.Y.S.2d 945, 947 (App. Div. 1994) ("While the Election Law equates residence with domicile, it does not preclude a person from having two residences and choosing one for election purposes provided he or she has "legitimate, significant and continuing attachments' to that residence.").

8. See infra text accompanying note 104 (describing factors that have contributed to increased mobility). 
residence.$^{9}$ For approximately forty-five percent of these households, the second residence had at one point been the household's primary residence. ${ }^{10}$

Dual residents, like permanent residents of a community, are subject to local taxes and to local zoning and housing codes. ${ }^{11}$ And like their permanent counterparts, dual residents depend heavily on local government for the provision of basic governmental services-including maintenance of public safety and public health, street maintenance, and public transportation-so vital to their daily lives. ${ }^{12}$ The lack of representation afforded to these dual residents raises a number of questions regarding the nature of representative democracy in the United States, ${ }^{13}$ particularly in light of a "well-established pattern of year-round residents' extracting high taxes from seasonal property owners." 14 This disparate tax treatment has often led to cries against taxation without representation, ${ }^{15}$

9. Brief for Plaintiffs-Appellants at 21, Wit v. Berman, No. 00-9482, 2002 U.S. App. LEXIS 21301 (2d Cir. Oct. 11, 2002) (citing U.S. Census Bureau, American Housing Survey, General Characteristics of U.S. Households (1995)). The last year in which detailed questions about second homes were asked was 1995. Id. The plaintiffs in Wit $v$. Berman, who brought suit to gain dual resident voting rights, hired Andrew A. Beveridge, a demographer and professor of sociology at Queens College, to analyze the American Housing Survey data presented in the lawsuit. Dr. Beveridge also analyzes census data as a consultant to The New York Times. Blaine Harden, Summer Owner Wants a Vote in Both Houses; Suit Says People Can be Residents of More Than One Place, N.Y. Times, June 1, 2001, at B1 [hereinafter Harden, Summer Owner]. The American Housing Survey statistics likely underestimate the actual number of citizens who qualify as dual residents because they look only at second-home owners, not renters. Many of those who split their time between two residences, for example, migrant farm workers who rent small cabins or live in barracks, are not taken into account.

10. Brief for Plaintiffs-Appellants at 21, Wit (No. 00-9482).

11. 1d. at $4-5,17$.

12. Id. at 25-26.

13. See infra Part 1.B.

14. Blaine Harden, Summer Residents Want Year-Round Voice, N.Y. Times, May 30, 2000, at Al [hereinafter Harden, Year-Round Voice] (quoting the opinion of James Hines, Director of Office of Tax Policy Research at the University of Michigan). See generally James Michael Dailey, Casenote, The Thin Line Between Acceptable Disparate Tax Treatment of Nonresidents and Unconstitutional Discrimination Under the Article IV Privileges and Immunities Clause: Lunding $v$. New York Tax Appeals Tribunal, 118 S. Ct. 766 (1998), 21 Hamline L. Rev. 563 (1998) (demonstrating that states discriminate against nonresidents by imposing higher taxes on them and discussing measures used by courts to combat this trend).

15. Fred Bayles, 'Seasonal' Residents Fight for Expanded Rights, USA Today, May 23, 2000 , at $6 \mathrm{~A}$ ("Non-residents argue that they often pay a majority of local taxes, yet have no say in how the revenue is spent. That raises a fundamental issue of taxation without representation."); Flesher, supra note 2 ("[I]n some of these towns you have a majority of property taxes being paid by nonresidents, and these people have absolutely no say in how their tax money is being spent."); Part-Time Residents Seek Full-Time Say, Record (N.J.), Aug. 21, 2000, at A3 (describing second-home owner's claim that denial of the vote "is a classic example of taxation without representation"). 
a principle whose "ideological roots can be traced at least as far back as the American Revolution." 16

Modern responses to the traditional disenfranchisement of dual residents have taken several forms. Close to a dozen states now permit nonresidents to vote on some local issues. ${ }^{17}$ Some authorize nonresident property owners to vote in special districts, ${ }^{18}$ while others permit local governments to enfranchise nonresidents at their discretion. ${ }^{19}$ Furthermore, legislation has been proposed to extend voting rights to permanent nonresidents in several other states. ${ }^{20}$ In a number of states that prohibit second-home owners from voting, citizens have begun to agitate for change-forming nonresident taxpayer associations and maintaining websites devoted to the issue. ${ }^{21}$

In addition, a number of disgruntled permanent residents and second-home owners have taken their claims to court, forcing the legal system to recognize the mounting tension in many second-home communities. For example, part-time residents in the Adirondack village of Speculator, New York, filed a federal lawsuit after year-round residents

16. Jamin B. Raskin, Legal Aliens, Local Citizens: The Historical, Constitutional and Theoretical Meanings of Alien Suffrage, 141 U. Pa. L. Rev. 1391, 1444 (1993) [hereinafter Raskin, Legal Aliens]; see also Bernard Bailyn, The Ideological Origins of the American Revolution 117, 209-21 (1967) (arguing that colonists experienced Parliament's illegal taxation as a "deliberate assault of power upon liberty").

17. Harden, Year-Round Voice, supra note 14.

18. See, e.g., Ariz. Rev. Stat. Ann. $\$ 48-404$ (West 2000) (permitting nonresident property owners to vote in pest control district); Colo. Rev. Stat. Ann. $\$ 37-41-104$ (West 1990) (enfranchising nonresident property owners in conservation and irrigation districts); Mont. Code Ann. \$7-13-2255 (2001) (enfranchising nonresident property owners in county water and sewer districts). Indiana, New Mexico, North Dakota, and Wyoming extend similar voting rights in special districts to nonresidents, and some Connecticut communities give nonresidents a vote on fiscal issues. Bayles, supra note 15.

19. See, e.g., Tenn. Code Ann. §6-20-106 (1998) (permitting nonresident property owners to vote in all municipal elections and referenda if approved by city board of commissioners).

20. In New York, efforts have been made since 1995 to generate support for a bill that would give nonresident property owners a right to vote on referenda that affect their taxes. Bayles, supra note 15. More recently, legislation was introduced that would give property owners the right to vote on all financial issues in their water, fire, and school districts. An Act to Amend the Town Law, in Relation to Allowing Property Owners in Special lmprovement Districts to Vote Upon Expenditures of Such Districts, Assem. 6151, 1999 Leg., Reg. Sess. (N.Y. 1999). In Michigan, a resolution was introduced to amend the state constitution "to permit nonresidents who pay ad valorem property tax . . . to vote on local issues, tax limit increases, or bond issues." S.J. Res. 14, 91st Leg., 1st Sess. (Mich. 2001). A similar amendment has been proposed in New Jersey to allow nonresidents to vote on local issues by absentee ballot. Assem. Res. 45, 209th Leg., lst Sess. (N.J. 2000).

21. See Ellen Barry, Second-Home Citizens: On Cape and Beyond, Seasonal Residents Fight to be Heard, Boston Globe, Aug. 31, 2000, at Al (noting the rise of taxpayer associations as the number of second homes increases); Bayles, supra note 15 (identifying a nonresident taxpayer association in Truro, Massachusetts, as well as a web site devoted to a group advocating voting rights for seasonal residents in South Pomfrett, Vermont). 
voted to spend $\$ 5.3$ million for a school catering to I03 students. ${ }^{22}$ In addition, a "group of vacation home owners in Michigan is considering an appeal to the U.S. Supreme Court over a ballot initiative that allowed a large surtax on second homes." ${ }^{23}$ In 1995, full time residents of Mountain Village, a Colorado ski resort town, sued in federal court after the town's charter gave second-home owners the right to vote in local elections. ${ }^{24}$ On appeal, the Tenth Circuit upheld the charter. ${ }^{25}$ More recently, the Second Circuit upheld New York's restrictive voting statutes against an Equal Protection challenge raised by several second-home owners who sued to gain the right to vote in local elections in both of their residential districts. ${ }^{26}$

This Note argues that dual residents, defined as those who would qualify as bona fide residents of a particular community, but for the fact that they already qualify as such in another community, should be enfranchised at the local level. ${ }^{27}$ Throughout this Note a distinction is drawn between "dual residents," who meet the requirements of bona fide residence set out in a state's election law, and nonresident property owners who, although affected by local governmental decisions regarding their property, do not dwell in the community or maintain connections sufficient to constitute bona fide residence. Part I presents arguments grounded in traditional democratic theory in favor of extending voting rights to dual residents at the local, as opposed to the national or statewide, level, and addresses several common objections often raised at the prospect of extending the vote to dual residents. Part II argues that excluding dual residents from voting in a second-home community simply because they are also registered to vote in another community violates the Equal Protection Clause. ${ }^{28}$ Part III explains why the judiciary, rather than the legislature, should be primarily charged with extending the franchise to dual residents.

22. Barry, supra note 21.

23. Id.

24. Id.

25. May v. Town of Mountain Vill., 132 F.3d 576, 576-77 (10th Cir. 1997).

26. Wit v. Berman, No. 00-9482, 2002 U.S. App. LEXIS 21301, at*3-*4 (2d Cir. Oct. 11, 2002).

27. The argument presented here thus differs from the work of Gerald Frug who seeks to diversify political communities by allowing individuals to vote in the region to which they feel most connected and by recognizing legitimate attachments to areas where electors shop and work as well as those in which they reside. Gerald E. Frug, City Making: Building Communities Without Building Walls 106-07 (1999). While Frug would permit an individual to vote in any community to which he feels a sense of attachment regardless of where he resides, this Note argues for allowing individuals to vote in multiple residential communities.

28. U.S. Const. amend. XIV, \$1. 


\section{Extending the Franchise to Dual Residents at the local Level: Practical and Theoretical Considerations}

Over the last century, the United States has become an increasingly mobile society. ${ }^{29}$ Although many individuals maintain legitimate connections sufficient to constitute residency in more than one location, they are frequently prevented from participating in local governance by election laws that restrict voting to a single location. Part 1 presents a number of compelling legal and normative positions that argue in favor of dual resident enfranchisement. Section A seeks to distinguish dual voting in local elections from dual voting in national or statewide elections. Section B presents arguments arising from traditional democratic theory that support expanding the franchise to those who qualify as bona fide residents of more than one community. Section $C$ raises and attempts to respond to several of the most common arguments against dual resident voting.

\section{A. Local versus National and Statewide Elections}

Allowing dual residents to vote twice in federal elections, for example, for President or Congress, would clearly violate a fundamental principle of American voting rights jurisprudence, namely "one person, one vote," 30 by affording these individuals two chances to be heard in the same election. ${ }^{31}$ Similarly, permitting dual residents to vote in two locations for state legislators may also result in dual representation by allowing these individuals the opportunity to vote for two different representatives to the state's lawmaking body-one in each part of the state in which they reside. ${ }^{32}$

29. See John R. Schmidhauser, Residency Requirements for Voting and the Tensions of a Mobile Society, 61 Mich. L. Rev. 823, 824 (1962) (noting that mobility has intensified in every decade since 1900 and citing statistics).

30. For a discussion of "one person, one vote," see infra Part 1.C.1.

31. Reynolds v. Sims, 377 U.S. 533, 562 (1964) (holding that votes for state legislators must be equally weighted and apportioned on a population basis and noting that "[i]t would appear extraordinary to suggest that a State could be constitutionally permitted to enact a law providing that certain of the State's voters could vote two, five, or 10 times for their legislative representatives, while voters living elsewhere could vote only once"); Sanford Levinson, Suffrage and Community: Who Should Vote?, 41 Fla. L. Rev. 545, 553-54 (1989) (arguing in favor of dual state citizenship within the United States, but maintaining that " $[\mathrm{m}]$ ultiple votes for federal offices would violate important principles of equal citizenship").

32. One could argue that a person who maintains two homes in two different states, rather than in two communities within a state, should be able to vote in state elections in both states, as such enfranchisement would not violate "one person, one vote" or lead to dual representation. See Levinson, supra note 31, at 554 (noting the benefits of "dual state citizenship and concomitant participation rights" in state elections). The argument here is confined to local elections, in part because the arguments arising from democratic theory are more persuasive at this level, and in part because a full analysis of the distinctions between dual residents with two homes in one state and dual residents with two homes in two different states is beyond the scope of this Note. 
Allocating the vote in local elections, however, presents a significantly different set of issues than those present in state or national elections. As David Martin noted with regard to multiple voting in the United States:

1 submit that we would regard it as objectionable, even fraudulent, for a person to vote twice within the same electoral cycle in two different locations, even if she did spend a portion of the year in each location. At least this is true of voting for higher level general-purpose legislative and executive branch positions. Voting at the municipal level, where revenue may be based primarily on property ownership and authority may be divided among a variety of bodies with specialized powers, presents different considerations. ${ }^{33}$

In contrast to dual voting in national or statewide elections, enfranchising dual residents in local elections in two residential communities does not lead to double representation because these residents would vote only once in a given election, not twice within the same community or for the same position.

ln addition, the considerations present in extending the vote at the local level have historically differed from those present at the state and national levels, and municipalities have at times been more flexible in expanding the franchise to reflect the needs and sentiments of their constituencies. During the colonial era, for example, the qualifications required to vote in local elections commonly deviated from those needed to vote in colonial or provincial elections. ${ }^{34}$

Distinctions between state and municipal voting rights were perpetuated during the revolutionary period. ${ }^{35}$ At that time, the most common difference between municipal voting rights and state suffrage was found in the property restrictions on voting. ${ }^{36}$ lncreasingly, urban residents who did not own real property were permitted to vote in municipal, but not state, elections if they met "either a personal property or a taxpaying requirement." ${ }^{37}$ Throughout this period, municipal voting rights tended to expand more rapidly than did the right to vote in state elections because of the pressure brought to bear on the political system by propertyless city dwellers. ${ }^{38}$ Similarly, decades before women were allowed to vote

33. David A. Martin, New Rules on Dual Nationality for a Democratizing Globe: Between Rejection and Embrace, 14 Geo. Immigr. L.J. 1, 26-27 (1999) (punctuation omitted) (emphasis added). For further discussion of the distinctions between local governments and national or state governments, see Richard Briffault, Who Rules at Home?: One Person/One Vote and Local Governments, 60 U. Chi. L. Rev. 339, 340-43 (1993) (noting typical characteristics of local government-specifically, "specialization, fragmentation, overlap, and boundary change" - that make local government "strikingly different from other levels of govermment").

34. Alexander Keyssar, The Right to Vote: The Contested History of Democracy in the United States 6 (2000).

35. Id. at 20.

36 . Id.

37. Id. at 21 .

38. Id. 
for federal and state offices, they were permitted to vote in municipal and school board elections. ${ }^{39}$ These expansions of the franchise illustrate some of the ways in which municipalities have adapted their election laws to changing urban conditions in order to meet the evolving needs of democratic governance.

\section{B. Government and the Consent of the Governed}

The American people have long objected to the notion that their interests could be "virtually represented" by others. The doctrine of virtual representation arose in the eighteenth century as a defense of the British parliamentary system of allocating votes, which left many disenfranchised. ${ }^{40}$ Those unable to vote directly were said to be virtually represented because their interests would be taken into account by a Parliament "engaged in the deliberative process of identifying and pursuing the common good of the entire commonwealth." 41 American colonists rejected this justification for their disenfranchisement in the British Empire, noting, "our privileges are all virtual, our sufferings are real.... We might have flattered ourselves that a virtual obedience would have exactly corresponded with a virtual representation. . . ."42

Ultimately this sentiment evolved into the belief that "representative government is legitimate only when those supposedly represented have had some direct say in the selection of the representatives." 43 This belief resonates in the influential writings of John Locke ${ }^{44}$ and the Declaration of Independence. It expresses the essence of American democracy-that the legitimacy of government rests on the consent of the governed. ${ }^{45}$ As moral philosopher Michael Walzer has noted, "[m]en and women are

39. Id. at $\mathbf{1 8 6 - 8 7 .}$

40. James A. Gardner, Liberty, Community and the Constitutional Structure of Political lnfluence: A Reconsideration of the Right to Vote, 145 U. Pa. L. Rev. 893, 909-10 (1997).

41. 1d. at 909; see also Bailyn, supra note 16, at 166-70 (discussing the doctrine of virtual representation); John Phillip Reid, The Concept of Representation in the Age of the American Revolution 50-62 (1989) (discussing theories of interest and virtual representation).

42. Bailyn, supra note 16 , at 168 (quoting the writing of Arthur Lee).

43. Gardner, supra note 40 , at 909-10; see also Bailyn, supra note 16 , at 173-74 (describing the developing notion of representation and the growing view that the binding power of the law "flowed from the continuous assent of the subjects of law").

44. See, e.g., John Locke, Two Treatises of Government 362 (Peter Laslett ed., Cambridge Univ. Press 1988) (1690) ("Governments cannot be supported without great Charge ... . But still it must be with his own Consent, i.e., the Consent of the Majority, giving it either by themselves, or their Representatives chosen by them."); see also James A. Gardner, Consent, Legitimacy and Elections: Implementing Popular Sovereignty Under the Lockean Constitution, 52 U. Pitt. L. Rev. 189, 205-13 (1990) (arguing that part of the Constitution "reflects the broad outlines of Locke's theory of popular sovereignty").

45. Raskin, Legal Aliens, supra note 16, at 1444 ("Here lies the very heart of the democratic idea: that governmental legitimacy depends upon the affirmative consent of those who are governed."). 
either subject to the state's authority, or they are not; and if they are subject, they must be given a say, and ultimately an equal say, in what that authority does," for "the rule of citizens over non-citizens, of members over strangers, is probably the most common form of tyranny in human history." 46

Excluding dual residents from the ballot prevents them from electing representatives who will protect their interests in their second-home communities, and works to separate "the shaping of the laws ... from the sharing of its consequences." 47 As the New York State Legislature noted in passing a bill that permits resident aliens to vote in local elections, "[t]he right to vote is the cornerstone of democracy, and voting empowers communities and individuals to elect representatives to speak, advocate, and act on their behalf in bodies that appropriate and allocate funds, make laws, and govern them." 48

One of the most troublesome areas in this regard relates to the disparate taxation of nonresidents, a measure employed by many states as a method of raising revenue without suffering political consequences. ${ }^{49}$ This disparate tax treatment has often led to cries against taxation without representation, a principle that has long played a role in the American democratic tradition..$^{50}$ ln short, so long as dual residents lack a vote, politicians remain largely unaccountable to many of those subject to their power. 51

46. Michael Walzer, Spheres of Justice: A Defense of Pluralism and Equality 61-62 (1983); see also Robert A. Dahl, Procedural Democracy, in Philosophy, Politics, and Society: Fifth Series 97, 97-100 (Peter Laslett \& James Fishkin eds., 1979) (defining underlying assumptions of human association which mandate equal participation for group members in decisionmaking processes).

47. Levinson, supra note 31 , at $\mathbf{5 5 2}$ (quoting Lea Brilmayer, Shaping and Sharing in Democratic Theory: Toward a Political Philosophy of Interstate Equality, 15 Fla. St. U. L. Rev. 389, 390 (1987)).

48. See N.Y. State Assem., Memorandum in Support of Legislation, An Act to Amend the Election Law, in Relation to Granting Certain Resident Aliens the Right to Vote in Local Elections, Assem. 2001-3903, Gen. Sess., at 1 (N.Y. 2001) [hereinafter Memorandum in Support of Legislation].

49. See sources cited supra note 14.

50. See sources cited supra notes $15-16$.

51. The one jurisdiction in America where such deliberate disenfranchisement is permitted is in the District of Columbia. As Jamin Raskin has noted, "Americans living in the District [of Columbia] are the only citizens of the United States today who have voting representation neither in Congress nor in their 'state' legislative sovereign." Jamin B. Raskin, Is This America? The District of Columbia and the Right to Vote, 34 Harv. C.R.C.L. 1. Rev. 39, 41 (1999). Although it has been argued that this disenfranchisement violates the Constitution's Equal Protection and Due Process Clauses, id. at 43, the courts have, thus far, refused to intervene, citing Article I of the Constitution, which commits to Congress "exclusive Legislation in all Cases whatsoever" over the District that is "the Seat of the Government of the United States." U.S. Const. art. I, $\$ 8, \mathrm{cl}$. 17. Because of its special constitutional treatment, the situation in the District of Columbia is distinguishable from the issue at hand. 


\section{Common Objections to Dual Resident Voting and Responses}

The extension of voting rights to dual residents has been challenged on both constitutional and normative grounds. The following section addresses a number of legal and policy-based arguments commonly raised against dual resident voting and attempts to provide responses to each. Specifically, this section focuses on the intersection of dual resident voting with the principle of "one person, one vote," concerns regarding dual residents' commitment to their second-home community, and an alleged increase of political influence for the wealthy.

1. "One Person, One Vote" and Vote Dilution. - At first glance it might appear that extending voting rights to dual residents violates a fundamental voting principle, namely "one person, one vote," either by giving some individuals the ability to vote twice or by impermissibly diluting the voting power of permanent residents. ${ }^{52}$ ln contrast to common perception, the principle of "one person, one vote" does not prevent individuals from voting in more than one location or for the same position within entirely different electoral systems. ${ }^{53}$ Instead, the principle attempts to ensure that, within any specific election, each voter casts an equally weighted vote. ${ }^{54}$

52. As the Supreme Court has noted, "the right of suffrage can be denied by a debasement or dilution of the weight of a citizen's vote just as effectively as by wholly prohibiting the free exercise of the franchise." Reynolds v. Sims, 377 U.S. 533, 555 (1964). Reynolds applied "one person, one vote" to the apportionment of state legislators, noting that legislators of governmental entities of general purpose and powers "represent people, not trees or acres." Id. at 562. Subsequently the principle was extended to units of local government in Avery v. Midland County, 390 U.S. 474, 480-81 (1968) and then to a more limited junior college district in Hadley v. Junior College District, 397 U.S. 50,56 (1970) (" $[\mathrm{A}] \mathrm{s}$ a general rule, whenever a state or local government decides to select persons by popular election to perform governmental functions, the Equal Protection Clause of the Fourteenth Amendment requires that each qualified voter must be given an equal opportunity to participate in that election ...."). The Hadley Court noted, however, that "one person, one vote" might not be required in a case where the state elects officials without normal governmental powers, whose activities disproportionately affect different groups. 1d. at 56. Such a case was found in Salyer Land Co. v. Tulare Lake Basin Water Storage District, 410 U.S. 719 (1973) ("one person, one vote," found not to apply in water district), and in Ball v. James, 451 U.S. 355 (1981) (same). Thus, in special districts, it is often acceptable to enfranchise all property owners, including second-home owners, in the district and to disenfranchise nonproperty owners.

53. See Martin, supra note 33, at 27 (noting that “' [o] ne person, one vote' is normally taken to mean that one does not vote in two places"). While it is true that one cannot vote in two places in the same election, "one person, one vote" in no way prohibits voting in two places in two separate elections.

54. See, e.g., Hadley, 397 U.S. at 56 (holding that votes must be weighted equally in junior college district); Avery, 390 U.S. at $485-86$ (finding that votes must be equally weighted within single local election district); Reynolds, 377 U.S. at 567 (holding that votes must be weighted equally within election for state legislators). Each of these cases dealt with the weight given to votes in a single election. None addressed the issue of allowing residents to vote in two separate elections. 
In this sense, the claim of disenfranchised dual residents resembles the claim of the plaintiff in Kramer $v$. Union Free School District No. 15. ${ }^{55}$ The plaintiff in Kramer was a thirty-one year old college-educated stockbroker who lived in his parents' home. ${ }^{56}$ Because he had no children and neither leased nor owned taxable real property, the state election law permitted him to vote in general elections, but not in school board elections. ${ }^{57}$ The Supreme Court held that the state's interest in limiting the franchise to those primarily interested in the outcome of the election was not sufficiently compelling to justify denying equal protection to the excluded residents. ${ }^{58}$ Just as the Kramer plaintiff, a permanent resident, was permitted to vote in multiple elections-both general and special district-without implicating "one person, one vote," so too dual residents can vote in multiple elections without violating this fundamental voting rights principle.

The constitutional permissibility of voting in more than one location is demonstrated most clearly by the fact that over a dozen states currently allow nonresidents to vote in local elections. ${ }^{59}$ The Constitution's complete silence on all matters of local governance ${ }^{60}$ leaves states with substantial power to experiment with varying methods of structuring local communities. The Supreme Court has taken note of "the immense pressures facing units of local government, and of the greatly varying problems with which they must deal," ${ }^{1}$ and has, therefore, concluded that " $[t]$ he Constitution does not require that a uniform straitjacket bind citizens in devising mechanisms of local government suitable for local needs and efficient in solving local problems." 62 Thus, a number of states, including Arizona, Colorado, Indiana, Montana, New Mexico, North Dakota, and Wyoming, offer nonresidents some voting rights in special districts, and in certain Connecticut communities nonresidents are permitted to vote on fiscal issues. ${ }^{63}$

Moreover, in upholding New York's restrictive voting statutes, the Second Circuit in Wit $v$. Berman relied almost exclusively on the state's

55. 395 U.S. 621 (1969).

56. Id. at 624 .

57. Id. at 625 .

58. Id. at 632 .

59. See supra notes $17-20$ and accompanying text; see also Levinson, supra note 31 , at 554 (noting that while the Constitution does not compel dual voting rights, this does not preclude states from voluntarily extending such rights); Gerald E. Neuman, "We Are the People": Alien Suffrage in German and American Perspective, 13 Mich. J. Int'l L. 259, 317-2I (1992) (discussing the relaxation of residency requirements at the local level and reviewing cases upholding enfranchisement of nonresidents).

60. Neuman, supra note 59 , at 314-15 \& 11.342 .

61. Avery v. Midland County, 390 U.S. 474, 485 (1968).

62. Id.; see also Holt Civic Club v. City of Tuscaloosa, 439 U.S. 60, 71 (1978) (emphasizing "the extraordinarily wide latitude that States have in creating various types of political subdivisions and conferring authority upon them").

63. See supra notes $17-19$ and accompanying text. 
interest in the orderly administration of elections. ${ }^{64}$ At no point in the opinion did the Second Circuit mention "one person, one vote," and its implication for dual resident voting. Surely this fundamental constitutional principle would have been referenced by the Wit court had it been a basis for refuting dual residents' claims. Instead, courts have generally upheld the enfranchisement of nonresident property owners, with identifiable interests to defend, ${ }^{65}$ and have, at times, spoken approvingly of efforts to include these individuals in a community's political process. ${ }^{66}$

The inclusion of dual residents in the local electorate has also been challenged on the grounds that such inclusion dilutes the voting power of permanent residents. At some level, this claim is correct in that any expansion of an electorate necessarily dilutes the voting power of the existing members of the electorate. ${ }^{67}$ Enfranchising dual residents dilutes the vote of permanent residents just as women's suffrage diluted the vote of men and black suffrage diluted the vote of whites. In these instances, dilution of the existing vote was acceptable and even required.

Unlike statutes that restrict the vote, which are subject to strict scrutiny, statutes that expand the right to vote, including those that enfranchise dual residents, are reviewed using a rational relation standard. ${ }^{68}$ Courts have found that a rational nexus between the state's goal and the means used to achieve that goal exists when the enfranchised class has a "substantial interest" in the subject of the election. ${ }^{69}$ A sub2002)

64. No. 00-9482, 2002 U.S. App. LEXIS 2130I, at *13-*16, *20-*21 (2d Cir. Oct. 11,

65. Neuman, supra note 59 , at 317 .

66. See, e.g., Diebler v. City of Rehoboth Beach, 790 F.2d 328, 339 (3d Cir. 1986) (Sloviter, J., concurring) (describing the city's "commendable effort to enfranchise nonresidents and to insure nonresidents' participation in the leadership of the City").

67. Raskin, Legal Aliens, supra note I6, at 1440 (noting that "every prospective new voting member theoretically dilutes the voting power of each current member or enriches the meaning of the political community for all").

68. This standard has been applied where nonresident property owners are enfranchised in general municipal elections, as well as in special district elections. See, e.g., Spahos v. Mayor of Savannah Beach, 207 F. Supp. 688, 692 (S.D. Ga. 1962) (municipal elections), aff'd, 371 U.S. 206, 206 (1962); May v. Town of Mountain Vill., 132 F.3d 576, 580 (10th Cir. 1997) (municipal elections); Duncan v. Coffee County, 69 F.3d 88, 94-95 (6th Cir. 1995) (school district election); Sutton v. Escambia County Bd. of Educ., 809 F.2d 770, 772 (11th Cir. 1987) (school board elections); Phillips v. Andress, 634 F.2d 947, 949-50 (5th Cir. Unit B Jan. 1981) (school board elections); Brown v. Bd. of Comm'rs, 722 F. Supp. 380, 380 (E.D. Tenn. 1989) (municipal elections); Bjornestad v. Hulse, 229 Cal. App. 3d 1568, 1593-94 (Ct. App. 1991) (water district).

One early exception to the application of rational review to statutes that expand the vote is found in Locklear v. N.C. Bd. of Elections, 514 F.2d 1152, 1154-56 (1975) (employing a "compelling state interest" standard), but later cases have criticized this decision. See, e.g., Duncan, 69 F.3d at 94 ("[W]e reject the standard advanced by the Fourth Circuit . . . in Locklear."); Phillips v. Beasley, 78 F.R.D. 207, 21 I (N.D. Ala. 1978) (criticizing Locklear's use of a compelling state interest standard), rev'd on other grounds sub nom. Phillips v. Andress, 634 F.2d 947.

69. Duncan, $69 \mathrm{~F} .3 \mathrm{~d}$ at 94 (finding rational nexus when enfranchised voters have a "substantial interest in the ... election"); Sutton, 809 F.2d at 772 (finding rational nexus 
stantial interest has, in turn, been found where nonresidents are affected by the outcome of the election, either because they contribute significantly to the county budget or because they use services provided by the municipality. ${ }^{70}$

In one of the earliest cases dealing with nonresident enfranchisement, the Supreme Court upheld a voting scheme for a seaside resort town that extended the franchise to nonresidents who owned property in the town. ${ }^{71}$ The town's charter had been revised multiple times in an effort to achieve a compromise between permanent and part-time residents, each wanting control over a town in which the nonresident minority owned a majority of the taxable property. ${ }^{72}$ The Supreme Court affirmed the district court's opinion that:

The objective of the legislature here was undoubtedly to permit those persons owning property within the municipality, many of whom were summer residents therein, to have a voice in the management of its affairs. This appears to be a rational objective and the plaintiffs have failed to show that the classification thereunder is arbitrary or unreasonable. ${ }^{73}$

Courts have also allowed states wide latitude in enfranchising nonresidents who own property within city limits and who are therefore subject to the city's taxing authority. ${ }^{74}$ Most recently, in May $v$. Town of Mountain Village, the Tenth Circuit upheld a municipal charter that enfranchised nonresident property owners in all municipal elections, against an Equal Protection claim of impermissible vote dilution launched by permanent

when voters "have a substantial interest in the operation" of the school system); Hogencamp v. Lee County Bd. of Educ., 722 F.2d 720, 722 (11 th Cir. 1984) (requiring only substantial interest, but finding that money contributed to school district does not constitute substantial interest); Andress, 634 F.2d at 950 (finding rational nexus when voters "have a substantial interest in the operation" of the school system); Neuman, supra note 59, at 317 (noting that courts generally uphold enfranchisement of nonresidents with identifiable interests to defend).

70. See, e.g., May, 132 F.3d at 581-82 (finding payment of taxes and interest in town governance constitutes substantial interest); Sutton, 809 F.2d at 774 (holding that attendance in schools and interest in provision of services qualifies as substantial interest); Collins v. Town of Goshen, 635 F.2d 954, 959 (2d Cir. 1980) (finding payment of taxes sufficient to give nonresidents substantial interest); Clark v. Town of Greenburgh, 436 F.2d 770,772 (2d Cir. 1971) (holding payment of taxes and receipt of municipal services qualifies as substantial interest); Bjormestad, 229 Cal. App. 3d at 1594 (finding nonresidents' interest in water district in area with limited water is substantial).

71. Spahos, 371 U.S. at 206.

72. Spahos, 207 F. Supp. at 690-91. Although this case was decided in 1962, before many of the most significant voting rights decisions, courts have continued to rely on its holding. See, e.g., May, 132 F.3d at 580-81; Collins, 635 F.2d at 958; Brown, 722 F. Supp. at 398.

73. Spahos, 207 F. Supp. at 692 (emphasis added).

74. See, e.g., Brown, 722 F. Supp. at 397-400 (permitting extension of franchise to property owners, but finding extension irrational and unconstitutional as applied in this case); Snead v. City of Albuquerque, 663 F. Supp. 1084, 1088-89 (D.N.M. 1987) (upholding extension of right to vote on city indebtedness referendum to county residents who owned property in city and paid taxes in preceding year), aff d, 841 F.2d 1131 (1987). 
town residents. ${ }^{75}$ The Tenth Circuit first noted that " $[w]$ here a law expands the right to vote causing voting dilution, the rational basis test has been applied by the vast majority of courts."76 The court went on to find that it was rational to include property owners-who had an interest in the town's property taxes, land use ordinances, capital improvement programs, issuance of bonds, special improvement districts, utilities, and power to condemn property-in the town's political process. ${ }^{77}$

In addition, while the considerations involved in allocating the vote in special purpose districts differ from those in general municipal elections, ${ }^{78}$ courts have been equally willing to permit the enfranchisement of nonresidents in these districts. For example, courts have upheld the right of a state to permit residents of a city with an independent school system to vote in county school board elections. ${ }^{79}$ The judiciary has similarly upheld the right of nonresidents to vote in local water, police, and fire districts. ${ }^{80}$

Dual residents, who spend a significant portion of time in each of two residences, contribute to the county budget through the payment of local property and other taxes on an equal basis with permanent residents. ${ }^{81}$ Dual residents also depend on the municipality for the provision of basic governmental services, including local street cleaning, water supply, and waste removal, and to maintain public safety, public health, and transportation services vital to their homes, families, personal prop-

75. May, 132 F.3d at 576-77.

76. Id. at 580 (alteration in original).

77. Id. at 582-83.

78. Unlike general municipal elections, special district elections are exempt from the "one person, one vote" rule that often prevents exclusion of nonproperty owners from the electorate. See supra note 52 .

79. Duncan v. Coffee County, 69 F.3d 88, 94-97 (6th Cir. 1995) (upholding inclusion of ol:t-of-district voters in school board elections so long as voters have substantial interest in election); Sutton v. Escambia County Bd. of Educ., 809 F.2d 770, 772 (11th Cir. 1987) (upholding statute permitting residents of city with independent school system to vote in county school board elections); Creel v. Freeman, 531 F.2d 286, 288-89 (5th Cir. 1976) (permitting residents of city to vote for members of county board of education).

80. See, e.g., Collins v. Town of Goshen, 635 F.2d 954, 954 (2d Cir. 1980) (water service district); Cantwell v. Hudnut, 566 F.2d 30, 31 (7th Cir. 1977) (police and fire service district); Bjornestad v. Hulse, 229 Cal. App. 3d 1568, 1593 (Ct. App. 1991) (water service district).

81. The principal local tax is the property tax. Property taxes generate seventy-five percent of local tax dollars, and inust be paid by all property owners regardless of residence. In addition, property taxes are not imposed on home owners alone. Permanent seasonal renters are indirectly subjected to local property taxes through their rental rate. The second principle tax is the sales tax, which accounts for seventeen percent of municipal own-source revenues, and is paid by nonresidents and residents on an equal basis. Local income taxes are relatively rare; a 1994 survey by the U.S. Advisory Commission on Intergovernmental Relations found that they exist in just fourteen states, and of the 4,111 jurisdictions that levy an income tax, over 2,800 are in Pennsylvania, and over 600 are in Ohio. Income taxes are most commonly used in large cities, such as New York City, Philadelphia, Detroit, and Washington D.C. See William D. Valente et al., Cases and Materials on State and Local Government Law 489, 616-18 (5th ed. 2001). 
erty, and daily lives. And like the second-home owners enfranchised in Mountain Village, Colorado, dual residents have a significant interest in local land use ordinances, capital improvement programs, bond issuances, special improvement districts, utilities, and the locality's power to condemn property. Because dual residents satisfy the "substantial interest" requirement, permitting them to vote in both residences would not impermissibly dilute the vote of permanent residents.

2. Insufficient Connection to Local Government. - Opponents of dual resident enfranchisement often argue that dual residents should be excluded from the electorate in their second-home community because they cannot be as attached to the community as are permanent residents. ${ }^{82}$ 1t has, however, been recognized in the context of dual citizenship, that "[a]ll of us have multiple loyalties, to family, community, church, college, club, or sports team, and they are not usually seen as inconsistent with allegiance to the nation." ${ }^{83}$ In fact, "[s] ocieties that lack or suppress those other affiliations, allowing only allegiance to the nationstate, are rightly condemned as totalitarian .... [T] here is no reason why national allegiance must ipso facto crowd out loyalty to another nation." ${ }^{84}$ Allegiance to a political community is a complex, multidimensional experience and, as a general rule, individuals can be loyal to more than one community.

Dual residents, in particular, often have sufficient ties to their second-home community to ensure their commitment to it. Many dual residents are economically dependent on income earned in a second-home community. ${ }^{85}$ Others have invested substantial resources in their homes and in the community. As bona fide residents, dual residents are deeply impacted by local policies and ordinances in both communities, ${ }^{86}$ particularly local tax and bond issues. ${ }^{87}$ These residents, who share in the burdens of residence, should share in the privileges, including the right to vote. ${ }^{88}$

Some might object to the idea that property ownership and taxpayer status provide the right to vote, given that such preconditions to voting have been gradually eliminated since the American Revolution and the

82. As David Martin has discussed with regard to dual citizen voting, "[o]ppositionists tend to assume that loyalty is one-dimensional; loyalty to a second dilutes or destroys loyalty to the first. Dual nationality then draws condemnation as akin to bigamy." Martin, supra note 33 , at 8 .

83. Id.

84. Id. at 9 .

85. See infra text accompanying notes 98-102 (discussing the economic dependence of migrant farmworkers on second-home communities).

86. See supra text accompanying notes 11-15.

87. For a discussion of local taxes, see supra note 81 .

88. See Virginia Harper-Ho, Noncitizen Voting Rights: The History, the Law and Current Prospects for Change, 18 Law \& lneq. 271, 295 (2000) (arguing that noncitzens who bear the same burdens as citizens should be entitled to vote at the local level). 
advent of Jeffersonian democracy. ${ }^{89}$ The argument here, however, rests not on property ownership or payment of taxes, in and of themselves, as sufficient to confer the right to vote. Rather, these factors serve as indications of membership in a political community, which, taken as part of dual residents' total commitment to the community, would constitute bona fide residence, if not for their having previously registered to vote in another community.

More importantly, the argument that individuals who are less committed to a community, but otherwise meet the requirements of bona fide residence, should be excluded from the electorate has been rejected in other legal contexts. Members of the military and student voters have repeatedly been found to have a right to vote in the communities in which they temporarily reside while in the army or attending school, ${ }^{90}$ even though many have "only a transitory stake in local or state affairs." It seems likely that the majority of students, who often remain in a community for only four years, have less interest in the community and greater ability to exit than do dual residents. Yet, students are considered part of the relevant political community, while dual residents are often excluded.

Similarly, under the Uniform and Overseas Citizens Absentee Voting Act, ${ }^{92}$ overseas voters, defined as "persons who reside outside the United States and who are or 'but for such residence would be' qualified to vote in the last domestic location in which they were domiciled," are permitted to vote in federal elections. ${ }^{93}$ These citizens, who live in other countries, are permitted to vote on national policies, but remain free from many of the effects of the policies they help to enact. Again it is unclear why residents of other countries should be enfranchised when dual residents, who are in fact subject to the laws of the municipality, frequently are not.

3. Increasing the Influence of the Wealthy. - The common perception is that most second-home owners are wealthy, and that extending the right to vote to these residents would serve only to increase the political influ-

89. See Kirk H. Porter, A History of Suffrage in the United States 48-76 (Greenwood Press 1969) (1918) (noting that in the period between the American Revolution and the Civil War, property and taxpayer qualifications at the state level tended to give way to the egalitarian ideology of Jeffersonian democracy). By 1975, both property and tax payment requirements had been abolished as preconditions for voting. U.S. Const. amend. XXIV, $\$ 1$ (rendering poll tax unconstitutional); Hill v. Stone, 421 U.S. 289, 300 (1975) (holding that rendering of property for tax purposes cannot be a condition of voting); City of Phoenix v. Kolodziejski, 399 U.S. 204, 213 (1970) (holding that ownership of real property cannot be condition of voting).

90. See infra notes $152-154$ and accompanying text.

91. Harper-Ho, supra note 88 , at 302 .

92. 42 U.S.C. $\$ 1973 f f(2000)$.

93. Samuel Issacharoff et al., The Law of Democracy 70 (2d ed. 2001). 
ence of a disproportionately influential group. ${ }^{94}$ According to the American Housing Survey, however, the median household income of those with a second residence is $\$ 52,000$, which is not dramatically higher than the median household income of $\$ 40,000$ for all American homeowner households. ${ }^{95}$ Furthermore, the survey does not account for the many individuals of lesser economic means who rent a second residence on a permanent seasonal basis.

In addition, vacation homeowners are by no means the only class affected by the limitation on voting to one residence. Another group that is greatly impacted is the so-called "snow birds," or retired senior citizens who spend the winter months in a warm southern climate and return to the north for the summer months. ${ }^{96}$ This is particularly troublesome given the steady increase in the elderly portion of the population. ${ }^{97}$

Moreover, among the supporters of an expansion of the franchise to dual residents are migrant farm workers. ${ }^{98}$ Far from being wealthy and privileged, migrant farm workers constitute "a clearly disadvantaged class which is generally illiterate and poorly informed of its legal rights." ${ }^{99}$ Many migrant workers are based in southern states, such as Texas and Florida, and travel north for part of the year, "returning to the same employer, same housing, same town, and same school district each year." 100 These workers "are employed, pay taxes . . . educate their children, belong to religious congregations, and otherwise contribute to the communities in which they live." 101 Yet because they are registered to vote in

94. See, e.g., Rick Brand, Rich Get Richer-And Another Vote?, Newsday (N.Y., Nassau \& Suffolk County), Aug. 16, 2001, at A32 (citing fears of creating a class of "landed wealthy and unduly influential people"); Flesher, supra note 2 (quoting Brenda Wright, attorney with the National Voting Rights Institute as saying "[extending the franchise to second-home owners] would really end up giving greater voting rights to the people who are well-off enough to afford vacation homes").

95. Brief for Plaintiffs-Appellants at 22, Wit v. Berman, No. 00-9482, 2002 U.S. App. LEXIS 21301 (2d Cir. Oct. 11, 2002).

96. See, e.g., James F. Lynch, Gimme a J, Gimme an E, Gimme an R . ., N.Y. Times, June 5, 1983, \$11, at 29 (describing "the influx of 'snow birds,' visitors seeking winter pastures greener than those in the Garden State"); Penny Singer, Family Firm Offers Elderly Luxury Living, N.Y. Times, Dec. 14, 1997, \$14, at 8 (describing "snow bird" residents of a senior home in Manhattan who also spend several months a year in Florida).

97. Samuel Issacharoff \& Erica Worth Harris, Is Age Discrimination Really Age Discrimination?: The ADEA's Unnatural Solution, 72 N.Y.U. L. Rev. 780, 803 n.112 (1997) ("In 1900 , only $4 \%$ of the population was 65 or older; in 1980 , that number increased to $11 \%$; by 2050 , that figure is projected to reach $24 \% . ")$.

98. Brand, supra note 94 (noting support of migrant farm workers for suit aimed at gaining duaI resident voting rights); Harden, Summer Owner, supra note 9 (same). In fact, the Farmworker Legal Services of New York filed a brief for amicus curiae in support of Appellants in Wil $v$. Berman to gain dual resident voting rights for migrant farm workers. See generally, Brief for Amicus Curiae Farmworker Legal Services of N.Y., Inc., in Support of Appellants, and Supporting Reversal, Wit v. Berman, No. 00-9482, 2002 U.S. App. LEXIS 21301 (2d Cir. Oct. 11, 2002).

99. Mid-Hudson Legal Servs., Inc. v. G. \& U. Inc., 578 F.2d 34, 37 (2d Cir. 1978).

100. Brief for Amicus Curiae at 4-5, Wit (No. 00-9482).

101. Id. at 5. 
one community, migrant farm workers are prevented from voting in a second community whose policies and laws equally affect their interests in local issues such as the availability of decent housing, zoning, and education policies and services, including the administration of school lunch programs and the provision of health related services. Extending the right to vote to dual residents "would-at least theoretically-increase the responsiveness of local officials to farmworker concerns." 102

\section{I. Enfranchising Dual Residents: The Constitution, the State, AND THE COURT}

In the United States, states are left with the primary responsibility of setting voter qualifications. The argument for extending the local franchise to dual residents in no way challenges this essential state right. Dual residents do not advocate expanding states' existing residency requirements because, by definition, dual residents qualify as bona fide residents of a given community. In contrast to individuals who are excluded from the franchise for failure to meet states' residency requirements, dual residents are prevented from voting by an "eligibility plus" requirement that excludes otherwise eligible voters simply because they are already registered to vote in another community. The issue, then, is not simply whether states as a normative matter should extend the franchise to dual residents, but rather whether as a federal constitutional matter, they are required to do so. Given the Court's clear hostility towards status-based differential treatment in the context of voting rights, this Note argues that states are likely prohibited from disenfranchising dual residents, unless tbey can justify their actions under strict judicial scrutiny.

The restriction against dual resident voting may have historically escaped equal protection review because for most of this nation's history travel was difficult and few individuals qualified as bona fide residents of more than one locale. In modern times, a large and growing number of Americans qualify as legitimate residents of two or more locales. According to 1995 census data, nearly ten percent of American households owned more than one residence. ${ }^{103}$ Many more, without the means to purchase a vacation home, rent a second home on a permanent seasonal basis. The increased number of two residence households is attributable to many factors:

Improved highways and air transportation make it easier for people to travel quickly and comfortably between two places. Modern communications technology and information systems make it easier for many to earn a living while spending much of their time at a residence distant from traditional business and employment centers. For others, like migrant farm workers, the 
transitory and seasonal nature of their work requires that they maintain two homes. 1mproved health care enables people to live longer and be more vigorous in their later years; older people may want to move to the country or to resort areas while keeping, and traveling to, their pre-retirement homes . . . . ${ }^{104}$ Many of these citizens, seeking to protect their rights in their secondhome communities, have taken their claims to court, forcing the judicial system to address, for the first time, the disenfranchisement of dual residents. ${ }^{105}$

Section A affirms the power of states to set reasonable residence requirements on the right to vote, and demonstrates that strict scrutiny review should be applied to state voting statutes that discriminate against a group of bona fide residents. Section $B$ discusses the use of restrictive status based classifications in voting statutes and describes the judicial distrust with which these classifications are viewed. Section $C$ analyzes a number of state interests that restrictive voting statutes allege to support. In particular, section $\mathrm{C}$ finds, first, that there is no compelling interest in limiting voting to one's domicile and, second, that while there is a compelling interest in preventing voter fraud, statutes which create a per se rule against dual resident voting are not narrowly tailored to meet the state's legitimate goal.

\section{A. Dual Resident Voting and the Equal Protection Clause}

1. Judicial Response to Discriminatory Voting Statutes: Strict Scrutiny Review. - Under the Constitution, states have the right to determine voter qualifications for both federal and state elections, ${ }^{106}$ so long as such qualifications do not discriminate against individuals in violation of the Constitution. ${ }^{107}$ As the Supreme Court has noted, "[t]he United States has

104. Brief for Plaintiffs-Appellants at 22, Wit v. Berman, No. 00-9482, 2002 U.S. App. LEXIS 21301 (2d Cir. Oct. 11, 2002); see also Brief for Amicus Curiae at 4, Wit (No. 009482) (describing seasonal nature of migrant farmworkers' employment).

105. For a discussion of second-home citizens' suits currently before state and federal courts, see text accompanying notes 22-26.

106. See, e.g., Oregon v. Mitchell, 400 U.S. 112, 124-25 (1970) (“[T]he Framers of the Constitution intended the States to keep for themselves . . . the power to regulate elections."); Lassiter v. Northampton County Bd. of Elections, 360 U.S. 45, 50 (1959) ("The States have long been held to have broad powers to determine the conditions under which the right of suffrage may be exercised ...."); The Federalist No. 52, at 326 (James Madison) (Clinton Rossiter ed., 1961) ("To have reduced the different [voting] qualifications in the different States to one uniform rule would probably have been as dissatisfactory to some of the States as it would have been difficult to the convention."); Geoffrey R. Stone et al., Constitutional Law 848 (3d ed. 1996) (describing the Court's past deference to states' voter qualifications).

107. Mitchell, 400 U.S. at 125 ("No function is more essential to the separate and independent existence of the States and their governments than the power to determine within the limits of the Constitution the qualifications of their own voters for state, county, and municipal offices ...."); Pope v. Williams, 193 U.S. 621, 632 (1904) ("[T] he privilege to vote in a State is within the jurisdiction of the State itself, to be exercised as the State 
no voters in the States of its own creation. The elective officers of the United States are all elected directly or indirectly by State voters." 108

Over the course of the nation's history a series of constitutional amendments have imposed limits on the right of states to set voter qualifications. For example, the Fifteenth Amendment, enacted in 1870, prohibits denying the vote on account of race, color, or previous condition of servitude; the Nineteenth Amendment, enacted in 1920, prohibits sex discrimination in setting voting qualifications; the Twenty-fourth Amendment, enacted in 1964, forbids the use of a poll tax as a prerequisite to voting for President, Vice President, or any member of Congress; and the Twenty-sixth Amendment, enacted in 1971, prevents states from denying the vote to citizens over eighteen years old on account of age.

Until the 1960s, the Supreme Court played a passive role in voting rights cases, generally deferring to the state's judgment in determining qualifications for voting. ${ }^{109}$ With the rise of the civil rights movement, however, Supreme Court doctrine regarding voting rights underwent a significant shift. The Court began to interpret the Constitution so as to remove from the states the sole power to set voter qualifications. In Reynolds $v$. Sims, the Court noted:

[T] he right of suffrage is a fundamental matter in a free and democratic society. Especially since the right to exercise the franchise in a free and unimpaired manner is preservative of other basic civil and political rights, any alleged infringement of the right of citizens to vote must be carefully and meticulously scrutinized. ${ }^{110}$

While the Court recognized that the Constitution does not confer the right to vote on any particular individual, ${ }^{11}$ it held that the Equal Protection Clause of the Fourteenth Amendment confers a right for each quali-

may direct [provided] no discrimination is made between individuals in violation of the Federal Constitution.").

108. Minor v. Happersett, 88 U.S. (21 Wall.) 162, 170 (1874). Article One of the Constitution provides that members of the House of Representatives be chosen by the same method as the electors of the most numerous branch of the state legislature. U.S. Const. art. $1, \S 2$. The Seventeenth Amendment similarly provides that U.S. Senators be elected by voters with the same qualifications as electors for the most numerous branch of the state legislature. 1d. amend. XVI1. Article Two further permits the states to set qualifications for choosing electors for presidential elections. 1d. art. II, $\$ 1$.

109. See, e.g., Lassiter, 360 U.S. at 45 (unanimously upholding statute requiring individuals to be able to read and write in order to vote); Breedlove v. Suttles, 302 U.S. 277, 283 (1937) (unanimously upholding statute requiring payment of poll tax as a precondition to voting). But see the White Primary Cases, including Nixon v. Condon, 286 U.S. 73 (1932), and Nixon v. Herndon, 273 U.S. 536 (1927), which in the years following Brown v. Board of Education, 347 U.S. 483 (1954), represented the "solitary . . Supreıne Court assault" on one technique of black disenfranchisement. Samuel Issacharoff \& Richard H. Pildes, Politics as Markets: Partisan Lockups of the Democratic Process, 50 Stan. L. Rev. 643, 652-53 (1998).

110. 377 U.S. 533, 561-62 (1964) (emphasis added).

111. Minor, 88 U.S. (21 Wall.) at 178 ("[T]he Constitution of the United States does not confer the right of suffrage upon any one ...."). 
fied voter to participate in the electoral system on an equal basis with other qualified voters. ${ }^{112}$

1n Kramer v. Union Free School District No. 15, the Court specified precisely which voters it deemed "qualified" to participate in a particular electoral system's political community. ${ }^{113}$ The Kramer Court held that "if a challenged state statute grants the right to vote to some bona fide residents of requisite age and citizenship and denies the franchise to others, the Court must determine whether the exclusions are necessary to promote a compelling state interest."114 Thus it would appear that statutes that grant the right to vote to bona fide residents with only one home, but deny that right to bona fide residents with homes in two communities, must be narrowly tailored to promote a compelling state interest in order to pass constitutional muster.

In Wil \%. Berman, however, the Second Circuit, the only federal appeals court to have addressed this Equal Protection issue to date, declined to apply strict scrutiny review to a New York statute restricting voting to a single residence. ${ }^{115}$ In arriving at this decision, the Second Circuit relied heavily on Burdick v. Takushi, a Supreme Court case that upheld Hawaii's ban on write-in votes in light of the state's registration system, which provided sufficient access to the ballot, and the state's interest in avoiding unrestrained factionalism and in preventing party raiding. 16 The Burdick Court noted that although "voting is of the most fundamental significance under our constitutional structure ... [i] t does not follow ... that the right to vote in any manner and the right to associate for political purposes through the ballot are absolute."'117 The Second Circuit further referenced the Burdick Court's pronouncement that:

Election laws will invariably impose some burden upon individual voters. Each provision of a code, "whether it governs the registration and qualifications of voters, the selection and eligibility of candidates, or the voting process itself, inevitably affects-at least to some degree-the individual's right to vote and his right to associate with others for political ends." Consequently, to subject every voting regulation to strict scrutiny and

112. Harris v. McRae, 448 U.S. 297, 322 n.25 (1980) (“[I]f a State adopts an electoral system, the Equal Protection Clause of the Fourteenth Amendment confers upon a qualified voter a substantive right to participate in the electoral process equally with other qualified voters."); San Antonio Indep. Sch. Dist. v. Rodriguez, 411 U.S. 1, 35 n.78 (1973) (recognizing the "protected right, implicit in our constitutional system, to participate in state elections on an equal basis with other qualified voters whenever the State has adopted an elective process for determining who will represent any segnent of the State's population”); Dunn v. Blumstein, 405 U.S. 330, 336 (1972) (“[T]his Court has made clear that a citizen has a constitutionally protected right to participate in elections on an equal basis with other citizens in the jurisdiction.").

113. 395 U.S. 621 (1969).

114. Id. at 627 (emphasis added).

115. No. 00-9482, 2002 U.S. App. LEXIS 21301, at *6-*7 (2d Cir. Oct. 1 f, 2002).

116. ld. (referencing Burdick, 504 U.S. 428, 438-40 (1992)).

117. ld. at *6 (quoting Burdick, 504 U.S. at 433) (alteration in original). 
to require that the regulation be narrowly tailored to advance a compelling state interest . . . would tie the hands of States seeking to assure that elections are operated equitably and efficiently. 118

While this assertion may be reasonable in the context of a ban on write-in ballots, the Wit court's reliance on Burdick seems misplaced in the context of an Equal Protection claim. In Burdick and other ballot access cases, courts are faced with the argument that restrictions on voters', candidates', and political parties' access to the ballot place impermissible burdens on voters' associational and First Amendment rights. ${ }^{119}$ In ballot access cases, courts utilize a balancing test, weighing "the character and magnitude of the asserted injury to the rights protected by the First and Fourteenth Amendments" against "the precise interests put forward by the state as justifications for the burden imposed by its rule." 120 Moreover, "[i]n passing judgment, the Court must not only determine the legitimacy and strength of each of those interests, it also must consider the extent to which those interests make it necessary to burden the plaintiff's rights."121

Under this test, a regulation will be subject to strict scrutiny if it places severe restrictions on voters' rights. ${ }^{122}$ If, however, the challenged law imposes only "reasonable, nondiscriminatory restrictions' upon the First and Fourteenth Amendment rights of voters, 'the State's important regulatory interests are generally sufficient to justify' the restrictions." 123 In contrast, the strict scrutiny standard is applicable, under an equal protection analysis, "to classifications affecting the exercise of fundamental rights," 124 which include the right to vote.

Having adopted Burdick's framework, the Wit court concluded that New York's Election Law was constitutional because it placed only "reasonable, nondiscriminatory restrictions" upon the rights of voters. ${ }^{125}$

118. Id. at $* 6-* 7$ (quotation omitted).

119. See Timmons v. Twin Cities Area New Party, 520 U.S. 351, 369-70 (1997) (holding that the burdens imposed by the fusion ban upon respondent's associational rights "were justified by 'correspondingly weighty' valid state interests in ballot integrity and political stability"); Burdick, 504 U.S. at 438 (upholding Hawaii's ban on write-in ballots and noting the Court's willingness to uphold "reasonable, politically neutral regulations that have the effect of channeling expressive activity at the polls"); Norman v. Reed, 502 U.S. 279, 290 (1992) (recognizing that state's interest in preventing misrepresentation and electoral confusion could justify properly tailored prohibition regarding candidates' use of party names); Storer v. Brown, 415 U.S. 724, 735-36 (1974) (finding that state's interest in preventing party splintering and factionalism justified one-year disaffiliation provision for independent candidates).

120. Anderson v. Celebrezze, 460 U.S. 780, 789 (1983); see also Timmons, 520 U.S. at 358; Burdick, 504 U.S. at 434; 26 Am. lur. 2d Elections $\$ 260$ (1996).

121. Anderson, 460 U.S. at 789; see also Timmons, 520 U.S. at 358 ; Burdick, 504 U.S. at 434; 26 Am. Jur. 2d Elections $\$ 260$.

122. Wit, 2002 U.S. App. LEXIS 21301, at*6 (citing Burdick, 504 U.S. at 434).

123. 1d. (quoting Burdick, 504 U.S. at 428).

124. Fulani v. Krivanek, 973 F.2d 1539, 1542-43 (11 th Cir. 1992) (citations omitted).

125. Wit, 2002 U.S. App. LEXIS 21301, at*6 (citing Burdick, 504 U.S. at 434). 
Thus, according to the court, New York's interest in the orderly administration of elections justified limiting voting to one, and only one, location.

In rejecting strict scrutiny and choosing to apply a "reasonable" standard of review, the Second Circuit seems to have treated the claim in Wit as a ballot access claim, rather than an Equal Protection claim. Yet, the plaintiffs in Wit challenged the constitutionality of a state law that denies the right to vote to a particular group of residents; ${ }^{126}$ they did not contend that restrictions on their access to the ballot placed impermissible burdens on their associational and First Amendment rights. Thus, the claim in Wit is more closely related to Kramer $v$. Union Free School District No. 15, where the right to vote in school board elections was denied to bona fide residents without children or property, ${ }^{127}$ and Carrington $v$. Rash, where the right to vote was denied to members of the military, ${ }^{128}$ than to Burdick, where write-in ballots were prohibited in order to maintain party stability. ${ }^{29}$ Because a state's interest in administering elections would likely be insufficient to survive strict scrutiny review, ${ }^{130}$ it is probable that had the Second Circuit characterized Wit as a voting rights case, rather than a ballot access case, the New York statutes under review would have been found to violate the Equal Protection Clause.

While states do retain the "unquestioned power to impose reasonable residence restrictions on the availability of the ballot,"131 statutes that prevent those who satisfy the requirements of bona fide residence from voting should be subject to strict scrutiny review, ${ }^{132}$ and thus, will be found to violate the Equal Protection Clause unless they are necessary to promote a compelling state interest.

126. According to the court, the plaintiffs in Wit claimed that:

$[\mathrm{T}]$ he Election Law . . . violates the Equal Protection Clause because it denies appellants the right to register to vote in elections in New York City even though, save for New York defining residency for voting purposes as the location of one's single permanent home ... they possess the same indicia of residency as those residents of New York City who are deemed qualified to register to vote.

2002 U.S. App. LEX1S 21301, at *1.

127. 395 U.S. 621, 622 (1969).

128. 380 U.S. $89,89-90$ (1965).

129. 504 U.S. at 430 .

130. The Supreme Court has expressed the view that administrative concerns cannot be tbe basis for preventing individuals from exercising their fundamental rights. See infra notes 170-171 and accompanying text. For a more complete discussion of New York's interest in limiting voting to one's domicile, see Part 11.C.1.

131. Carrington, 380 U.S. at 91 ; see also Kramer, 395 U.S. at 625 ("States have the power to impose reasonable citizenship, age, and residency requirements on the availability of the ballot.").

132. Mixon v. Ohio, 193 F.3d 389, 405 (6th Cir. 1999) ("If residents of the relevant jurisdiction are excluded from participation, as in Kramer, then the court subjects the legislation to strict scrutiny."). 
2. The Residence Requirement. - Residence is generally considered a reasonable basis for inclusion in a political community. ${ }^{133}$ The Supreme Court has noted that " $[\mathrm{a}] \mathrm{n}$ appropriately defined and uniformly applied requirement of bona fide residence may be necessary to preserve the basic conception of a political community." ${ }^{34}$ Residence provides "a useful predictor of the frequency with which an individual will be affected by the actions" of a given government, and ensures that members of the community have sufficient interest in the community. ${ }^{135}$ Some have argued that residence is an appropriate qualification because public decisionmaking often requires individuals to sacrifice some short term desires in order to obtain long-term benefits. Thus:

Normal political debate will undoubtedly produce disagreement about what those benefits ought to be, who ought to share in them, and who should bear the burdens of producing them. But to add nonresidents to that debate would likely create a schism over the objectives themselves. This schism would develop between those who view the objectives of a political entity solely as a nine-to-five sanctuary and those who view it in significantly broader terms. ${ }^{136}$

While those who view a political entity solely as a "nine-to-five sanctuary" surely lack sufficient interest in the entity as a whole to justify enfranchisement, dual residents, who reside in the community and would be qualified to vote therein if not for their having previously registered to vote in another community, fall among those who view the entity in significantly "broader terms." ${ }^{137}$ Indeed, modern courts have acknowledged

133. Neuman, supra note 59, at 315; see also Note, The Right to Vote in Municipal Annexations, 88 Harv. L. Rev. 1571, 1577 (1975) (describing functions served by residency requirement in local governments). While residence is a reasonable basis for inclusion in the political community, it is by no means essential to defining the electorate. In fact, some Americans who reside abroad are permitted to vote in Federal elections. See supra text accompanying notes 92-93. While residency may be a strong marker for community membership, there can be other legitimate markers, such as citizenship, property ownership, or the powers exercised over subjects. See Note, supra, at 1578.

134. Dunn v. Blumstein, 405 U.S. 330, 343-44 (1972); see also Shenton v. Abbott, 15 A.2d 906, 908 (Md. 1940) (noting that the object of constitutional provision "prescribing residence as a qualification for the exercise of the elective franchise was not only to identify the voters and to prevent fraud but also to assure that each voter will become in fact a member of his community and take an interest in its government").

135. Neuman, supra note 59, at 315; see also Friends of Jim Usry for Mayor Campaign v. Matthews for Mayor Campaign, 453 A.2d 1360, 1362 (N.J. Super. Ct. App. Div. 1982) ("The residence requirement necessary for [voter] registration insures that only the individuals who have a stake in the outcome of the election by reason of their residency within the community are allowed to vote.").

136. Melvyn R. Durchslag, Salyer, Ball, and Holt: Reappraising the Right to Vote in Terms of Political "Interest" and Vote Dilution, 33 Case W. Res. L. Rev. 1, 33 n. 140 (1982).

137. 1d. 
that individuals with sufficient connections to multiple communities can be bona fide residents of more than one community at a time. ${ }^{138}$

In this sense, the claims of dual residents for local representation differ from those of the plaintiffs in Holt Civic Club $v$. City of Tuscaloosa. ${ }^{139}$ In Holt, residents of a small, unincorporated community on the outskirts of Tuscaloosa, Alabama, challenged the constitutionality of Alabama statutes which subjected the community to the city's police and sanitary regulations, to the criminal jurisdiction of the city's courts, and to the city's power to license businesses, trades, and professions, but left it without the opportunity to participate in the political processes of the city. ${ }^{140}$ In rejecting the plaintiffs' argument for enfranchisement, the Court distinguished the Holt plaintiffs from the disenfranchised plaintiffs in Kramer $v$. Union Free School District No. 15, ${ }^{141}$ noting that in Kramer and other similar cases where the franchise was judicially extended to an excluded group " $[t]$ he challenged statute . . . denied the franchise to individuals who were physically resident within the geographic boundaries of the governmental entity concerned." 142 In the words of the Court, "a governmental unit may legitimately restrict the right to participate in its political processes to those who reside within its borders." 143 The Court thus refused to expand Tuscaloosa's definition of bona fide residence to include

138. Sec, e.g., People v. O'Hara, 754 N.E.2d 155, 159 (N.Y. 2001) ("[I]n this modern and mobile society, an individual can maintain more than one bona ficle residence."); $c f$. Gallagher v. Dinkins, 343 N.Y.S.2d 960, 961 (App. Div. 1973) (holding that where an individual has two residences "where he maintains significant and legitimate attachments, it is for him to decide which address he considers as his voting address"), aff'd, 299 N.E.2d 681 (N.Y. 1973).

The fact that modern courts have begun to recognize that an individual can maintain more than one bona fide residence raises issues of line drawing. In other words, it might be possible for some individuals to claim the right to vote from three or four bona fide residences. While this is certainly a theoretical possibility, in practice it seems unlikely that individuals would be able to meet the full qualifications for bona fide residency in multiple locations. If, however, an individual meets these qualifications, that individual should be permitted to vote in each community on the same basis as other qualified bona fide residents.

139. 439 U.S. 60 (1978).

140. Id. at $61-63$.

141. 395 U.S. 621 (1969).

142. Holl, 439 U.S. at 68.

143. Id. at 68-69. In the wake of Holt, courts that have reviewed nonresidents' claims for an extension of the franchise have focused on the geographical distinction set out in Holt, and have left the state 10 define the relevant political community entitled to vote in both general and special district elections. See, e.g., Mixon v. Ohio, 193 F.3d 389, 406 (6th Cir. 1999) (finding claims that residents of a school district who were prevented from voting in mayoral election were unconstitutionally disenfranchised analogous to claims in Holt and deferring to state legislature to define the geographic electorate for municipal elections); Massad v. City of New London, 652 A.2d 531, 536 (Conn. Super. Ct. 1993) (denying nonresident property owners claim for inclusion in budget and tax reform elections despite evidence of disparate tax treatment, based on right of state to exclude those outside the relevant geopolitical unit); Chasan v. Vill. Dist. of Eastman, 523 A.2d 16, 25 (N.H. 1986) (rejecting claim of unconstitutional disenfranchisement of nonresident 
those not physically residing within the city who were nonetheless subject to its authority.

Scholars have criticized the Supreme Court's reliance on geography in defining the relevant community for voting purposes and disregard for the extent and type of power wielded over disenfranchised groups. ${ }^{144}$ In reality, the Court does address the power wielded over the Tuscaloosa residents, though only in a footnote, and concludes that Tuscaloosa lacked "the vital and traditional authorities of cities and towns to levy ad valorem taxes, invoke the power of eminent domain, and zone property for various types of uses." 145 It is likely that had the municipality exercised such authority, the Court would have found the case more closely analogous to Evans v. Cornman, ${ }^{146}$ in which Maryland was compelled to enfranchise residents of a federal enclave who had chosen to reside beyond the borders of the state. Indeed, rather than rely on geography as a legitimate basis of disparate treatment, the Court has been urged to identify a set of powers which, "if exercised over nonresidents who are not permitted to vote, would be subject to strict scrutiny." 147 Unlike the limited power that Tuscaloosa exercised over nonresidents, dual residents are fully subject to ad valorem taxing, power of eminent domain, and zoning authority in each residence. If being subject to these "vital and traditional authorities of cities and towns" 148 requires an extension of the franchise, dual residents should be granted the right to vote.

More importantly, unlike the Holt plaintiffs, dual residents argue not for an expansion of a given community's bona fide residence requirements, but rather for a right to vote once they have met such requirements in full. Like other bona fide residents, dual residents "are physically resident within the geographic boundaries of the governmental entity concerned." 149 Unlike other bona fide residents, dual residents are prevented from voting by a status based classification-they are prevented from voting in one local community simply because they are additionally qualified to vote in another community. This issue is identical to the one presented in Kramer, in which some district residents, otherwise qualified by age and citizenship, were prevented from voting in school

property owners owning over ninety percent of property in water district in light of state's power to require residents be part of geopolitical community).

144. Durchslag, supra note 136, at 33-35; The Supreme Court, 1978 Term, 93 Harv. L. Rev. $60,146-49$ (1979). Though the need to define an electorate may be essential to the functioning of local government, there is no particular reason for the defining characteristic to be geography. Note, supra note 133, at 1578. In fact, other distinctions, such as property ownership or the powers exercised over subjects, could serve equally well. Id. Thus, some have noted that while there is a compelling interest in local government, "the arbitrariness of the residency requirement is its price." Id.

145. Holt, 439 U.S. at 73 n.8.

146. 398 U.S. 419 (1970).

147. The Supreme Court, 1978 Term, supra note 144, at 148.

148. Holt, 439 U.S. at 73 n.8.

149. Id. at 68. 
board elections by an "eligibility plus" requirement. ${ }^{150}$ ln Kramer, the Court held that restrictions that discriminate between groups of bona fide residents must be strictly scrutinized and will be found to violate the Equal Protection Clause if they are not necessary to promote a compelling state interest. As one court has summarized:

The lesson of Holt and Kramer is an important one: If residents of the relevant jurisdiction are excluded from participation, as in Kramer, then the court subjects the legislation to strict scrutiny. If, however, the legislation merely concerns extraterritorial jurisdiction over non-residents, courts employ rational basis review, granting the States wide latitude to create political subdivisions and exercise state legislative power. ${ }^{151}$

Since dual residents qualify as bona fide residents of a given locale, the question that remains to be answered is whether, in light of Kramer and its progeny, status based classifications restricting dual resident voting can survive strict scrutiny review.

\section{B. Status Based Classifications in Voting Statutes: A Fear of Bloc Voting}

Since the 1960s, the Supreme Court has repeatedly struck down state statutes that discriminate against residents of a given community based on their status, or group identification. For example, in Carrington $v$. Rash, the Court invalidated a Texas statute that denied the right to vote to any member of the military who moved to Texas during the course of duty, until the individual completed his or her military service. ${ }^{152}$ The Court held that although the state has the power to require that voting applicants actually fulfill the requirements of bona fide residence, if they do qualify as residents "they, as all other qualified residents, have a right to an equal opportunity for political representation." 153

Similarly, when faced with cases dealing with the right of students to register to vote in their school's community, rather than in their parents' community, courts have held that per se rules barring student voting violate the Equal Protection Clause by denying bona fide residents the right to vote. ${ }^{154}$ Thus, being categorized as a member of the military or as a

150. Kramer v. Union Free Sch. Dist. No. 15, 395 U.S. 621, 623-26 (1969).

151. Mixon v. Ohio, 193 F.3d 389, 405 (6th Cir. 1999).

152. 380 U.S. $89,89-90(1965)$.

153. 1d. at 94 .

154. See, e.g., Williams v. Salerno, 792 F.2d 323, 328 (2d Cir. 1986) (holding that per se rule against residence at student dormitory violates equal protection); Whatley v. Clark, 482 F.2d 1230, 1234 (5th Cir. 1973) (finding statutory presumption that college students have not acquired voting residence in campus home violates equal protection); Newburger v. Peterson, 344 F. Supp. 559, 563 (D.N.H. 1972) (invalidating state statute prohibiting registration of students intending to leave state after college, and finding that requirement of "indefinite intention" to remain in state failed to support a compelling state interest in a "day of widespread planning for change of scene and occupation"); Hershkoff v. Bd. of Registrars of Voters, 321 N.E.2d 656, 664 (Mass. 1974) (finding that if students have an intention to make their campus residence their hoine "for the time at least," it becomes their domicile "even if they intend to move later on"); Wilkins v. Bentley, 189 N.W.2d 423, 
student is insufficient to justify a restriction on the franchise if the other requirements of bona fide residence are met. Furthermore, the Court in Kramer expressed a general distrust of status based classifications, noting:

[T] he deference usually given to the judgment of legislators does not extend to decisions concerning which resident citizens may participate in the election of legislators and other public officials. ... The presumption of constitutionality and the approval given "rational" classifications in other types of enactments are based on an assumption that the institutions of state government are structured so as to represent fairly all the people. However, when the challenge to the statute is in effect a challenge of this basic assumption, the assumption can no longer serve as the basis for presuming constitutionality. ${ }^{155}$

Given the Court's reluctance to uphold status based classifications, one should query why states persist in using them. It seems likely that states rely on status based exclusions when they fear that enfranchising a particular sector of the population will result in the enactment of policies deemed harmful to the community of already enfranchised residents. In the context of dual resident voting, statutes limiting voting to one community may stem from fear that enfranchised dual residents would vote as a bloc and reject measures that permanent residents support. ${ }^{156}$

The Supreme Court addressed an identical issue in Carrington $v$. Rash. In that case, the state of Texas argued that excluding members of the military from the local electorate was necessary to protect the local

426-27 (Mich. 1971) (concluding that statute creating presumption against student voter residency in locale of school violated due process). As the court in Shivelhood $v$. Davis noted:

Times have changed; mobility has greatly increased. . . . Students, as well as other members of the population, are directly and importantly affected by the legislators, executive officials and laws that govern the communities in which they reside while attending school. Thus, those student [sic] who have their bona fide domiciles in the communities in which they reside while attending school, and thus are more closely tied to these communities than they are to the communities in which their parents live, should be permitted to vote in their school communities.

336 F. Supp. 1111, 1116 (D. Vt. 1971).

155. Kramer, 395 U.S. at 627-28.

156. See, e.g., Bayles, supra note 15 (citing concern that enfranchised nonresidents could make decisions that injure permanent residents and lead to animosity between the two groups); Amitai Etzioni, Summer-Share Citizenship?, N.Y. Times, June 1, 2000, at A29 (discussing the threat to local culture posed by extending the franchise to part time residents).

There is, however, some evidence that the fear of differential bloc voting may be unfounded. Voting records from the Colorado town of Mountain Village, whose municipal charter permits nonresident property owners to vote in municipal elections, indicate that the two groups have identical voting patterns. Barry, supra note 21 (citing Linda Check, town clerk of Mountain Village). In addition, Bill Hattrick, former mayor of Southampton, a town with a large population of second-home owners, has expressed a belief that second-home owners are likely to be among the strongest supporters of local development, education, and preservation. Brand, supra note 94 . 
civilian community from being overwhelmed by a "concentrated balloting of military personnel." 157 The state also argued that enfranchising these individuals might cause "[1]ocal bond issues [to] fail and property taxes [to] stagnate at low levels because military personnel are unwilling to invest in the future of the area." 158 The Supreme Court emphatically rejected these arguments and held that "fencing out" a sector of the population from the franchise out of fear of the way it might vote is constitutionally impermissible. ${ }^{159}$

Likewise, in justifying the exclusion of students from the franchise, states have expressed concerns about entrusting individuals with only a transitory interest in the political community with the right to influence more permanent policymaking in their temporary community. Courts have found this rationale insufficient to justify the exclusion of students, who otherwise qualify as bona fide residents of the community, from the franchise, noting:

[1] $t$ is no longer constitutionally permissible to exclude students from the franchise because of the fear of the way they may vote. . . . Fears have been expressed in the past when new groups have been granted the franchise, and these fears have proven to be largely unfounded. The fear that students will vote radically different from the bulk of the electorate is problematical at this point. However, as the U.S. Supreme Court stated . . . "[c]ompetition in ideas and governmental policies is at the core of our electoral process ...." The right to vote means the right to vote for the candidate of one's choice regardless of ideology. ${ }^{160}$

In addition, in Dunn $v$. Blumstein, the seminal case invalidating durational residence requirements, the Supreme Court expressly held that political differences of opinion cannot be the basis for excluding any group of persons from the franchise. ${ }^{161}$ Thus,

[T] he fact that newly arrived [residents] may have a more national outlook than longtime residents, or even may retain a viewpoint characteristic of the region from which they have come, is a constitutionally impermissible reason for depriving them of their chance to influence the electoral vote of their new home State. ${ }^{162}$

Just as the Constitution forbids distinguishing between newly arrived and long-term residents, it would also appear to bar distinguishing between residents who have no other home and residents who have a second home in another location. So long as dual residents have sufficient

157. Carrington, 380 U.S. at 93.

158. Id.

159. Id. at 94 .

160. Wilkins v. Bentley, 189 N.W.2d 423, 433 (Mich. 1971) (footnote and citation omitted) (emphasis added).

161. 405 U.S. 330,355 (1972).

162. Id. at 355-56 (quoting Hall v. Beals, 396 U.S. 45, 53-54 (1969) (Marshall, J., dissenting)). 
ties to the community to meet the requirements of bona fide residence, excluding them from the franchise in order to suppress their potentially contrary viewpoint seemingly violates the Equal Protection Clause.

\section{Withstanding Strict Scrutiny Review: Meeting the "Compelling State Interest" and "Narrowly Tailored" Requirements}

As discussed above, voting statutes that discriminate against individuals who meet the state's requirements for bona fide residence should be subject to strict scrutiny review. In order to survive strict scrutiny review, a state must prove, first, that the statute under review is necessary to promote a compelling state interest and, second, that the statute is narrowly tailored to achieve the state's goal. ${ }^{163}$ Thus, in order to determine whether limiting voting to one location by equating residence with domicile in election law statutes violates the Equal Protection Clause, it is necessary to analyze both the interest such a restriction might support and the breadth of the restriction itself. If the limitation is only rationally related to the goal of the state, it should be invalidated as an impermissible infringement on the fundamental right to vote.

1. Domicile, Voting, and Local Govermment. - As a legal concept, domicile is used when it is important to ensure that an individual's legal interests be determined by one set of laws. ${ }^{164}$ Domicile is, therefore, an appropriate test for questions of judicial jurisdiction, and the determination of basic aspects of civil status such as marriage, and intestate succession, where legal consistency and the orderly administration of legislative and judicial functions are required. ${ }^{165}$ Indeed, it was the administrative value of the domicile concept that seems to have primarily motivated the Second Circuit in Wit v. Berman to uphold New York's restrictive voting statutes. ${ }^{166}$ Although the Second Circuit recognized that "[d]omicile as a rule may have its philosophical defects," it concluded that the use of dom-

163. See Kramer v. Union Free Sch. Dist. No. 15, 395 U.S. 621, 632 (1969) (requiring statutes that selectively enfranchise residents to be "tailored so that the exclusion of [the] class is necessary to achieve the articulated state goal"); Harper v. Va. Bd. of Elections, 383 U.S. 663, 670 (1966) ("We have long been mindful that where fundamental rights and liberties are asserted under the Equal Protection Clause, classifications which migbt invade or restrain them must be closely scrutinized and carefully confined.").

164. Restatement (Second) of Conflict of Laws \$11(1) cmt. c (1989) (“A man may go to many different states during his lifetime. Yet it is desirable that some of his legal interests should at all times be determined by a single law.").

165. 1d.; see also Willis L. M. Reese, Does Domicil Bear a Single Meaning?, 55 Colum. 1. Rev. 589, 589 (1955) (noting the importance of domicile when dealing with "judicial jurisdiction, choice of law and governmental burdens and benefits").

166. No. 00-9482, 2002 U.S. App. LEXIS 21301, at *13-*16, *20-*21 (2d Cir. Oct. 11, 2002). From the outset it should be noted that the issue of administrability was not before the court in this case. Wit $v$. Berman came before the Second Circuit on appeal from the District Court's dismissal "of appellants' complaint alleging that the New York State Election Law violates the equal protection rights of citizens who have homes in multiple communities by denying them the right to vote in multiple local elections." ld, at ${ }^{*} 1$. Because this case was decided on a motion to dismiss, no factual record was presented to 
icile in voting statutes nonetheless, "has enormous practical advantages over the alternatives." 167 1n reaching this conclusion, the court noted that:

[T] he administrative problems that interests-based rules would cause for thousands of registrars of voters render those rules virtually unthinkable. Voter registration is generally a nondiscretionary function of local government carried out by low level officials. Absent meaningful guidance, some registrars (even in the same precinct) would use a "whatever-you-say" approach, others will adopt a "show-me-beyond-a-reasonable-doubt" stance, while yet others will resort to ad hoc, ad hominem, or whimsical standards.

Given the need for workable standards, determination of where one may vote based on interests in electoral outcomes is not a manageable rule. ${ }^{168}$

This Note argues that only those residents who meet the requirements of bona fide residence should be permitted to vote. ln registering these dual residents, election officials would follow the same procedure used to register individuals with only one residence. The bona fide residence requirements set out in the state election law, and already in effect throughout the state, provide a workable framework and "meaningful guidance" to local election officers charged with registering dual residents. Moreover, the successful implementation of dual resident voting in the second-home communities such as Mountain Village, Colorado, has demonstrated that enfranchising dual residents in two communities does not create conflicting expectations or disturb the electoral process in either community. ${ }^{169}$

More generally, the Supreme Court has also expressed the view that "States may not casually deprive a class of individuals of the vote because of some remote administrative benefit to the State." 170 Thus, "if there are other, reasonable ways to achieve those goals with a lesser burden on constitutionally protected activity, a State may not choose the way of greater interference." ${ }^{71}$ The Supreme Court has, therefore, held that the goal of promoting administrative expediency is insufficient to justify a durational residence requirement on the right to vote, ${ }^{172}$ and to receive welfare benefits. ${ }^{173}$

warrant the court's conclusion that eliminating the single voting residence restriction on the ballot would result in chaotic elections. Id. at *14.

167. Id. at $* 15$.

168. Id. at *13.

169. In Mountain Village, second-home owners are permitted to mail in ballots for all local elections. Bayles, supra note 15.

170. Carrington v. Rash, 380 U.S. 89,96 (1965).

171. Dunn v. Blumstein, 405 U.S. 330,343 (I972).

172. Memorial Hosp. v. Maricopa County, 415 U.S. 250, 267 (1974).

173. Shapiro v. Thompson, 394 U.S. 618, 636 (1969), overruled in part on other grounds by Edelman v. Jordan, 415 U.S. 651, 670-71 (1974). 
In addition to the administrative convenience of equating residence with domicile, residence has also been defined as domicile in statutes setting qualifications for voting on the ground that there should be one, and only one, location in which each person receives governmental benefits and bears governmental burdens. ${ }^{174}$ Thus, "it is the state of domicil which allows a man to vote and to hold public office. Conversely, this state can subject the individual to various types of personal taxation and ... can impose an inheritance tax upon all of his intangibles." 175 Yet, dual residents do not conform to this model. Dual residents live in two communities, are subject to local ordinances and regulations, and assume the burdens of local residence, including the burden of local taxes, in each community. ${ }^{176}$ In this regard, "[i]nterest balancing demands participation by all who are called upon to bear the burdens of securing some more general benefit." 177

Limiting voting to one location, based on the idea that one can bear a special relationship with only one community, seemingly ignores the reality of modern society, in which individuals do in fact bear such relationships with more than one local government. Thus, some maintain that an expansion of the meaning of residence beyond domicile in voting statutes is "what should happen when constitutional law meets evolving demographic reality." 178 As Professor Richard Briffault has noted:

We are not just a mobile society; we are also a commuter society. Most people no longer reside in the locality in which they work, and they no longer confine their weekly travel, shopping, social, cultural or other routine activities to the community in which they reside. The statement of a southern California woman-" 'I live in Garden Grove, work in Irvine, shop in Santa Ana, go to the dentist in Anaheim . . . and used to be president of the League of Women Voters in Fullerton.' "-is emblematic of the multijurisdictional lives most metropolitan area residents lead. ${ }^{179}$

Though individuals share some sense of identity and mutual interest with others living in their place of residence, that sense is reduced by a concurrent sense of identity with other jurisdictions that play an equally important part in an individual's life. ${ }^{180}$ Thus, in modern society, "the

174. Beale, supra note 5, at 4-5; Reese \& Green, supra note 5, at 571 n.61.

175. Reese, supra note 165 , at 589 (footnote omitted).

176. For a discussion of local burdens, including local taxing burdens, see supra notes 81 \& 86-88 and accompanying text.

177. Durchslag, supra note 136 , at 36 .

178. Harden, Summer Owner, supra note 9 (quoting statement of Richard Briffault).

179. Richard Briffault, Our Localism: Part II-Localism and Legal Theory, 90 Colum. L. Rev. 346, 413 (1990) [hereinafter Briffault, Our Localism] (footnote omitted); see also Neuman, supra note 59, at 315 (noting that the importance of residence in a single community as a precondition of membership in a political community may be "exaggerated by reliance on the mental image of the small unitary republic in which people live, work, and carry on all their other important activities").

180. Briffault, Our Localism, supra note 179 , at $413-I 4$. 
mystic quality with which the term 'community' often invests these shared interests-the hint of some organic unity of the individual and the place-is hard to sustain." 181 Indeed, this identification with multiple jurisdictions, so prevalent in the modern world, has, as noted above, led some courts to acknowledge that individuals can be bona fide residents of more than one community at a time. ${ }^{182}$ As a result, a state's interest in limiting voting to one's domicile, based on the relationship forged between the individual and the local government, can hardly be seen as compelling.

2. Prevention of Voter Fraud. - A second purpose often used to justify limiting the right to vote to one location through the equation of domicile with residence has been the legitimate need of states to prevent voter fraud. ${ }^{183}$ Yet, courts have often invalidated voting restrictions designed to prevent fraud on the grounds that less restrictive means of achieving the stated ends were available. ${ }^{184}$ In the context of dual resident voting, states have a legitimate interest in adopting a system that ensures that qualified voters vote only at the local level in their second-home community. Yet, a complete bar on dual resident voting is a far more restrictive measure than that which is needed to achieve this goal.

One less restrictive alternative has been implemented in New York to allow resident aliens to vote in local elections. ${ }^{185}$ In order to prevent these "local voters" from voting in national or statewide elections, the bill requires distinctively colored registration forms, lists of special local voters, and the adjustment of voting machines to accept votes from special local voters. ${ }^{186}$ A similar system could be created to allow dual residents to vote in local elections. ${ }^{187}$ A second solution, already successfully in use

181. 1d. at 414.

182. See sources cited supra note 138 .

183. The compelling need to prevent voter fraud in federal elections was illustrated by the 2000 presidential election. The National Commission on Federal Election Reform was formed in early 2001 in response to the enormous problems that occurred during that election. Both the Senate and the House of Representatives soon passed bills aimed at preventing voter fraud based on the Commission's recommendations. See Press Release, National Comm'n on Fed. Election Reform, Election Reform Bills Passed by Congress Reflect Recommendations of the National Commission on Federal Election Reform (Apr. 6, 2002), available at http://www.reformelections.org/data/press/network/bills passed.php (on file with the Columbia Law Reviezv).

184. See, e.g., Dumn v. Blumstein, 405 U.S. 330, 349-54 (1972) (maintaining that adequate means of ascertaining bona fide residence on an individualized basis existed, so as to preclude presumption of nonresidence from failure to satisfy the waiting period requirements of durational residence laws); Kramer v. Union Free Sch. Dist. No. 15, 395 U.S. 621, 632-33 (1969) (finding that state voting statute failed strict scrutiny review because it was both over- and under-inclusive).

185. See An Act to Amend the Election Law, in Relation to Granting Certain Resident Aliens the Right to Vote in Local Elections, Assem. 3903, 2001 Leg., Gen. Sess. $\$ 1$ (N.Y. 2001).

186. Memorandum in Support of Legislation, supra note 48, at 1.

187. Several numicipalities other than New York also authorize noncitizen voting in municipal and school board elections. Raskin, Legal Aliens, supra note 16, at 1460-67 
in Mountain Village, Colorado, is to send nonresident voters a special absentee mail-in ballot. ${ }^{188}$

Creation of a separate ballot and electorate within a state is certainly not a novel solution. Indeed, the use of separate qualifications and registration and different ballots for different offices has historically been part of the American electoral tradition. ${ }^{189}$ Furthermore, states already authorize the creation of special ballots for "special federal voters," who move out of their district within thirty days of the next election and so cannot register to vote in their new district, 190 and for "special presidential voters," those previously qualified voters who move out of the United States but maintain the right to vote in some federal elections. ${ }^{191}$ Just as special ballots have been created to accommodate these voters, who are permitted to vote in federal or presidential elections only, ${ }^{192}$ special ballots could, without difficulty, be prepared for local voters, permitting dual residents to vote for local offices in a given community, either at the polls or though a mail-in response. Thus, although the prevention of voter fraud has been recognized as a compelling state interest, a complete bar against dual resident voting is insufficiently tailored to survive the requirements of strict scrutiny review.

(highlighting several examples of noncitizen voting at the local level that could serve as models for other municipalities). Presumably, these municipalities have instituted administrative procedures for preventing noncitizens from voting in state and national elections. In addition, in many parts of Canada, nonresident property owners are permitted to vote in all local elections. See, e.g., City of Grand Forks, Elections, at http:// www.city.grandforks.bc.ca/city/elections.asp (last visited Aug. 2, 2002) (on file with the Columbia Law Review) (permitting nonresident property owners to vote in local elections both where they live and where they own property); Municipality of North Cowichan, Voter's Guide (Apr. 30, 2002), at http://www.northcowichan.bc.ca/voter_guid.htm (on file with the Columbia Law Review) (same).

188. Bayles, supra note 15 .

189. See, e.g., Van Winkle v. Crabtree, 55 P. 831, 831-32 (Or. 1899) (summarizing state constitutional and statutory provisions that authorize electors to vote for state officers in any county in the state, congressional officers in any county of their congressional district, and county officers in the election precinct where they reside, and require "the county clerk to provide two ballot boxes, marking one 'General,' and the other 'State and District,' and providing that ballots of persons not entitled to vote for county officers shall be placed in the latter, and ballots of persons entitled to vote for county officers in the former"); see also supra text accompanying notes 34-39 (describing the historical variation in qualifications for local and state elections).

190. See, e.g., N.Y. Elec. Law $\$ 11-102$ (McKinney 1998) (providing that previously qualified voters who move out of state or from one county to another within less than thirty days prior to the next election shall be entitled to vote in federal elections for the offices of President and Vice President); id. \$11-104(1)(a) (providing that person qualified to vote for President or Vice President may request special ballot).

191. See, e.g., id. $\$ 11-200$ (permitting previously qualified voters who move out of the United States to vote in federal elections).

192. See, e.g., id. $\$ 7-124$ (illustrating form of ballot for special federal voters); id. § 7125 (illustrating form of ballot for special presidential voters). 


\section{Prospects for Change: Political Lockups and the Need for Judicial Action}

Major expansions of the franchise, for example the admission of blacks and women into the electorate, have often been explained through reference to one of two models. Some maintain that these expansions have been achieved through political efforts rather than judicial action. ${ }^{193}$ According to this view, it is the "standing citizenry, after hearing and debating appeals from the voteless, that must extend rights of political membership to disenfranchised outsiders seeking entry and equality." 194 1t is, therefore, essential to educate voters and increase public awareness of dual resident voting so that those who are currently enfranchised may be persuaded to extend the vote. ${ }^{195}$

Others, however, view this argument skeptically, and are reluctant to rely on current members of the electorate, who have a vested interest in maintaining the status quo, to expand the franchise to include unrepresented groups. ${ }^{196}$ As John Hart Ely has noted, "[we] cannot trust the ins to decide who stays out, and it is therefore incumbent on the courts to ensure not only that no one is denied the vote for no reason, but also that where there is a reason [it] had better be a very convincing one." ${ }^{197}$ According to Ely, "unblocking stoppages in the democratic process is what judicial review ought preeminently to be about, and denial of the vote seems the quintessential stoppage." ${ }^{198}$ Judicial intervention is required wben the political market systematically malfunctions, leaving the democratic process itself undeserving of trust. ${ }^{199}$

Systematic malfunctions of the political system can result from "political lockups" of power. Political markets, like economic markets, are vulnerable to anticompetitive behavior. ${ }^{200}$ It is often possible for political actors to manipulate the "rules of engagement to protect established powers from the risk of successful challenge." 201 Political lockups can be caused by "a precommitment pact among existing elites that frustrates

193. Raskin, Legal Aliens, supra note 16 , at 1432, 1438-41.

194. 1d. at 1432. Raskin further argues that it is Inore democratic to permit enfranchised members of the existing political community, rather than judges, to extend the vote. ld. at 1431-32.

195. See Harper-Ho, supra note 88, at 294 (arguing that increasing public awareness of policy rationales for extending the right to vote is essential to any expansion of the electorate).

196. It is in the rational self-interest of enfranchised members of a political community to resist the addition of new members, as any inclusion of additional voters theoretically dilutes the voting power of each current member. Raskin, Legal Aliens, supra note 16 , at 1440 .

197. John Hart Ely, Democracy and Distrust 120 (1980).

198. 1d. at 117.

199. Id. at 102-03.

200. Issacharoff \& Pildes, supra note 109 , at 646 .

201. Id. 
easy penetration by outsiders." 202 In such a situation, "[i]ncumbents do not have to change the existing rules of competition to remain in office as long as they possess the power to fend off challengers." ${ }^{203}$ Incumbents in communities with dual residents have little incentive to risk a loss of their continued control by extending the ballot to these potential "challengers."

The political lockup in second-home communities is exacerbated by the fact that an effective appeal to the legislature is unlikely in a substantial number of instances. Many dual residents maintain homes in two separate states, thereby precluding a meaningful appeal to a relevant state legislature. In addition, petitioning Congress for the enactment of federal legislation in this area is likely to be unfeasible because the power to set requirements for voting in state and local elections is left to the states. ${ }^{204}$ Where the democratic political process stagnates in such a manner, the courts must act to destabilize the system. ${ }^{205}$

An analogy can be drawn to the history and eventual demise of the durational residence requirement. ${ }^{206}$ The use of durational residence requirements as a precondition to voting can be traced back in English legal history at least as far as $1413 .{ }^{207}$ Like current prohibitions against dual resident voting, the historical purpose of these requirements seems to have been to prevent "undesirables, immigrants, and outsiders," whose views may have differed from those of long-term residents, from participating in the political system. ${ }^{208}$ Despite their widespread use, scholars argued that the increased mobility of modern society rendered durational residence requirements unreasonable, as they left many without the ability to vote. ${ }^{209}$ Some concluded that the solution to the problem of the mobile voter lay in uniform federal legislative action. ${ }^{210}$ Others advocated increased judicial activism. ${ }^{211}$

202. Id. at 651. Issacharoff and Pildes extend Ely's ideas beyond a civil libertarian focus on individual rights and minority group interests to the task of "constructing the core structure of the political process itself." Id. at 710 .

203. Id. at 709.

204. See supra notes $106-109$ and accompanying text.

205. Issacharoff \& Pildes, supra note 109, at 699, 702 (arguing for judicial destabilization of attempted political lockups).

206. The author would like to express her thanks to Dr. Adinah Pelman for her help in developing this analogy.

207. David Cocanower \& David Rich, Residency Requirements for Voting, 12 Ariz. L. Rev. 477, 484 (1970).

208. Id.

209. Schmidhauser, supra note 29 , at $828-30$.

210. Id. at 839-40 (arguing for direct Congressional action to create uniformity across the country and which would embody full recognition of the highly mobile nature of modern American society).

211. Cocanower \& Rich, supra note 207, at 509 ("That durational residency requirements are of ancient vintage does not mitigate against their probable unconstitutionality."). 
In 1970, Congress passed an amendment to the Voting Rights Act, ${ }^{212}$ which prohibits denying the vote in any presidential election to any citizen for failure to comply with any state durational residence requirement. The Supreme Court upheld the validity of the Act based on the constitutional right to interstate travel and on the enforcement clause of the Fourteenth Amendment. ${ }^{213}$ While the amendment effectively ended the political lockup of presidential elections, it did nothing to increase representation at the state and local levels.

Less than two years later, in Dunn v. Blumstein, the Supreme Court held that state durational residence requirements, requiring voters to have been bona fide residents of the state or political subdivision for a prescribed length of time before being granted the right to vote in state or local elections, are unconstitutional unless they are necessary to satisfy a compelling state interest. ${ }^{214}$ The Court found that the state's alleged interest in protecting the "purity of the ballot box," preventing voter fraud, and having knowledgeable voters was insufficient to justify restricting the fundamental right to vote. ${ }^{215}$ Because uniform federal legislation is impossible, and mass local legislation is highly unlikely in the context of dual resident voting, the responsibility of eliminating an unconstitutional burden on the fundamental right to vote once again falls on the courts.

\section{Conclusion}

Throughout most of this nation's history, the restriction on voting in more than one location, through the equation of domicile with residence in many voting statutes, went largely unnoticed because travel was difficult and most people qualified as bona fide residents in only one community. In modern times, many factors have converged to make the United States a highly mobile country, in which many individuals from across the economic spectrum qualify as bona fide residents of more than one community. State election statutes, however, have not kept pace with changing demographic realities and needs of democratic governance, and have continued to draw distinctions between those who reside in more than one community and those who do not.

Voting rights jurisprudence regards with suspicion status based classifications and generally subjects statutes that create such distinctions to strict scrutiny. Statutes that prevent bona fide dual residents from exercising their fundamental right to vote within a community violate the Equal Protection Clause unless they are narrowly tailored to promote a

212. 42 U.S.C. $\$ 1973$ aa-1 (2000).

213. See Oregon v. Mitchell, 400 U.S. 112, 114 (1970) (noting that " $[t]$ here is adequate constitutional basis for the residency provisions of the Act in $\S 5$ of the Fourteenth Amendment, as . . . durational residence requirements abridge the right of free interstate migration").

214. 405 U.S. 330,337 (1972).

215. 1d. at 345-46. 
compelling state interest. It thus remains for the courts to actively destabilize a political situation unlikely to resolve itself through normal political channels. 